\title{
C-C Stretching Raman Spectra and Stabilities of Hydrocarbon Molecules in Natural Gas Hydrates: A Quantum Chemical Study
}

\author{
Yuan Liu and Lars Ojamäe
}

Linköping University Post Print

Tweet

N.B.: When citing this work, cite the original article.

Original Publication:

Yuan Liu and Lars Ojamäe, C-C Stretching Raman Spectra and Stabilities of Hydrocarbon Molecules in Natural Gas Hydrates: A Quantum Chemical Study, 2014, Journal of Physical Chemistry A, (118), 49, 11641-11651.

http://dx.doi.org/10.1021/jp510118p

Copyright: American Chemical Society http://pubs.acs.org/

Postprint available at: Linköping University Electronic Press

http://urn.kb.se/resolve?urn=urn:nbn:se:liu:diva-113497 


\title{
C-C Stretching Raman Spectra and Stabilities of Hydrocarbon
}

\section{Molecules in Natural Gas Hydrates - A Quantum Chemical Study}

\author{
Yuan Liu and Lars Ojamäe ${ }^{\dagger}$ \\ Department of Chemistry, IFM, Linköping University, SE-58 183 Linköping, Sweden \\ †Corresponding author:lars@ifm.liu.se
}

\section{Keywords:}

Quantum-chemical ab initio computations, ice clathrates, organic molecules, cavities, interaction energies, Raman vibrational spectroscopy

\begin{abstract}
:
The presence of specific hydrocarbon gas molecules in various types of water cavities in natural gas hydrates (NGHs) are governed by the relative stabilities of these encapsulated guest molecule - water cavity combinations. Using molecular quantum-chemical dispersion-corrected hybrid density functional computations, the interaction energies $\left(\Delta E_{\text {host-guest }}\right)$ and cohesive energies $\left(\Delta E_{c o h}\right)$, enthalpies and Gibbs free energies for the complexes of host water cages and hydrocarbon guest molecules are calculated at the $\omega \mathrm{B} 97 \mathrm{X}-\mathrm{D} / 6-311++\mathrm{G}(2 \mathrm{~d}, 2 \mathrm{p})$ level of theory. The zero point energy effect of $\Delta E_{\text {host-guest }}$ and $\Delta E_{\text {coh }}$ is found to be quite substantial. The energetically optimal host-guest combinations for seven hydrocarbon gas molecules $\left(\mathrm{CH}_{4}, \mathrm{C}_{2} \mathrm{H}_{6}\right.$, $\mathrm{C}_{3} \mathrm{H}_{6}, \mathrm{C}_{3} \mathrm{H}_{8}, \mathrm{C}_{4} \mathrm{H}_{8}, \mathrm{i}-\mathrm{C}_{4} \mathrm{H}_{10}$, and $\mathrm{n}-\mathrm{C}_{4} \mathrm{H}_{10}$ ) and various water cavities (D, ID, T, P, H and I) in NGHs are found to be $\mathrm{CH}_{4} @ \mathrm{D}, \mathrm{C}_{2} \mathrm{H}_{6} @ \mathrm{~T}, \mathrm{C}_{3} \mathrm{H}_{6} @ \mathrm{~T}, \mathrm{C}_{3} \mathrm{H}_{8} @ \mathrm{~T}, \mathrm{C}_{4} \mathrm{H}_{8} @ \mathrm{~T} / \mathrm{P} / \mathrm{H}$, i- $\mathrm{C}_{4} \mathrm{H}_{10} @ \mathrm{H}$, and $\mathrm{n}-\mathrm{C}_{4} \mathrm{H}_{10} @ \mathrm{H}$, as the largest cohesive energy magnitudes will be obtained with these host-guest combinations. The stabilities of various water cavities enclosing hydrocarbon molecules are evaluated from the computed cohesive Gibbs free energies: $\mathrm{CH}_{4}$ prefer to be trapped in a ID cage; $\mathrm{C}_{2} \mathrm{H}_{6}$ prefer $\mathrm{T}$ cages; $\mathrm{C}_{3} \mathrm{H}_{6}$ and $\mathrm{C}_{3} \mathrm{H}_{8}$ prefer $\mathrm{T}$ and $\mathrm{H}$ cages; $\mathrm{C}_{4} \mathrm{H}_{8}$ and $\mathrm{i}-\mathrm{C}_{4} \mathrm{H}_{10}$ prefer $\mathrm{H}$ cages; and ${ }_{n}-\mathrm{C}_{4} \mathrm{H}_{10}$ prefer I cages. The vibrational frequencies and Raman intensities of the $\mathrm{C}-\mathrm{C}$ stretching vibrational modes for these seven hydrocarbon molecules enclosed in each water cavity are computed. A blue shift results after the guest molecule is trapped from gas phase into various water cages due to the host-guest interactions between the water cage and hydrocarbon molecule. The frequency shifts to the red as the radius of water cages increases. The model calculations support the view that $\mathrm{C}-\mathrm{C}$ stretching vibrations of hydrocarbon molecules in the water cavities can be used as a tool to identify the types of crystal phases and guest molecules in NGHs.
\end{abstract}




\section{INTRODUCTION}

Natural gas hydrates (NGHs) are ice-like inclusion compounds. The host lattice is made up of hydrogen bonding water molecules, and hydrocarbon gas molecules (also called guest molecules) are encapsulated in various water cavities of the host framework. ${ }^{1-4}$ Different crystal phases of hydrates can be formed at appropriate pressure and temperature conditions, such as I, II, H, and some unusual phases (TS-I, ${ }^{5}$ HS-I, ${ }^{6} \mathrm{sK},{ }^{7} \mathrm{MH}-\mathrm{III},{ }^{8-9}$ and "filled ice"9-10). ${ }^{1}$ Six types of polyhedral cavities are included in these phases, shown in Figure 1, which are dodecahedral (D) cavities $\left(5^{12}\right)$, irregular dodecahedral (ID) cavities $\left(4^{3} 5^{6} 6^{3}\right)$, tetrakaidecahedral (T) cavities $\left(5^{12} 6^{2}\right)$, pentakaidecahedral $(\mathrm{P})$ cavities $\left(5^{12} 6^{3}\right)$, hexakaidecahedral $(\mathrm{H})$ cavities $\left(5^{12} 6^{4}\right)$, and icosahedral (I) cavities $\left(5^{12} 6^{8}\right)$, respectively. ${ }^{1}$ The detailed structure information of the unit cell of various crystal phases is given in Table 1 .

The NGHs play an important role in the energy and environment fields. ${ }^{1-4,11}$ The pipelines of oil and natural gas may be blocked by chunks of NGH under certain conditions. Most notably, NGHs are considered to constitute a promising energy resource in the near future due to the tremendous carbon content in the NGH deposits on earth. It has been estimated that the amount of carbon in NGH deposits under the ocean floor and in the permafrost is at least twice the amount of that in all the fossil fuels combined. ${ }^{1}$ However, the problems that may arise from the exploitation of NGHs must be considered. If a large amount of NGH deposits under the ocean floor is released rapidly it may induce geological disasters, and the release into the atmosphere of methane gas from NGH deposits could aggravate global warming. ${ }^{1}$

Due to the crucial roles played by NGHs, many experimental and theoretical efforts have made to study these systems. ${ }^{12-18}$ Experimentally, Raman, NMR, and other spectroscopic tools are the regular means to study NGHs. Especially, Raman spectroscopy has been used to identify the type of crystal phase, ${ }^{19-21}$ type of guest molecule, ${ }^{19}$ cage occupancy, ${ }^{21}$ and hydration number, ${ }^{21-22}$ to monitor the nucleation and growth processes in real-time, ${ }^{23}$ to study phase transformations, ${ }^{24-25}$ and to detect the location of NGH deposits. ${ }^{26-27}$ Based on Raman spectroscopy measurements, the characteristics of symmetric $\mathrm{C}-\mathrm{H}$ and $\mathrm{C}-\mathrm{C}$ stretching vibration of various guest molecules trapped in water cavities of sI, sII, and sH phase have been mapped out, which can be conveniently used to identify the types of crystal phase and guest molecule. ${ }^{19}$ The cage occupancy and hydration number can be determined through deconvolution of vibrational bands. ${ }^{21}$ The formation process of methane hydrate has been studied in real-time through Raman spectroscopy measurements of the C-H stretching vibrational mode. ${ }^{23}$ Uchida et al. studied the structural transition of methane-ethane mixed gas hydrates as a function of the content of $\mathrm{C}_{2} \mathrm{H}_{6}$ employing Raman spectroscopic observations. ${ }^{25}$ Hester et al. measured oceanic gas hydrates near the seafloor using a seagoing Raman spectrometer. ${ }^{27}$

Theoretically, molecular dynamics (MD) simulations and quantum-chemical calculations are the most often used techniques to study NGHs. ${ }^{28-31}$ The nucleation, growth, and dissociation process has been investigated by MD simulations in the last few years. ${ }^{32-38}$ In the quantum-chemical investigations most focus has been on the 
interaction between host and guest molecules, ${ }^{39-40}$ stability and diffusion of guest molecules in water cavities of clathrate hydrates, ${ }^{41-44}$ and phase transitions. ${ }^{45-46}$ Liu et al. evaluated the performance of twenty density functional theory (DFT) methods for the description of the intermolecular interaction in methane hydrates. ${ }^{39}$ Roman-Perez et al. calculated the adsorption energies of different guest molecules captured in the water cavities from clathrate hydrates based on DFT. ${ }^{43} \mathrm{Li}$ et al. studied the barriers of $\mathrm{H}_{2}$ and $\mathrm{CH}_{4}$ diffusion through the water framework in hydrates using dispersion-corrected DFT. ${ }^{42}$ The ice-methane clathrate phase transition was studied by periodic hybrid $a b$ initio-DFT computations with force-field corrections by Lenz and Ojamäe. ${ }^{45}$ Only relatively few theoretical studies investigated the molecular vibrations of guest molecules encapsulated in the water cavities of clathrate hydrates. Tse and later Hiratsuka et al. studied the vibrational spectrum of methane $\mathrm{CH}_{4}$ in the sI hydrate using periodic first-principles MD simulations. ${ }^{47-48}$ Ikeda and Tarakura studied the $\mathrm{C}-\mathrm{H}$ frequency shift under a methane hydrate phase transition using Car-Parrinello simulations. ${ }^{46}$ Ramya et al. studied the vibrational and librational modes of methane trapped in the small and the large cage of the sI phase by molecular quantum-chemical computations using a dispersion-corrected functional. ${ }^{49}$

Molecular quantum-chemical computations, where the guest molecules and the cages from the hydrate structures are represented by cluster models, is an efficient way to study host-guest interactions. ${ }^{30-31,40-41,44,49-52}$ However, in earlier studies it has been seen that unreasonable deformations of the models of water cavities in some cases occur, ${ }^{53}$ and some water cage structures have been optimized with the oxygen atoms fixed. ${ }^{54}$ This behavior can be avoided by employing a proper low-energy H-bond network. ${ }^{55-56}$ Earlier studies mainly focused on $\mathrm{CH}_{4}, \mathrm{CO}_{2}$, and $\mathrm{H}_{2}$ encapsulated in the water cages of clathrate hydrates, and studies on other hydrocarbon gas molecules enclosed in water cavities of NGHs are still scarce. In this article, seven kinds of hydrocarbon gas molecules $\left(\mathrm{CH}_{4}, \mathrm{C}_{2} \mathrm{H}_{6}, \mathrm{C}_{3} \mathrm{H}_{6}, \mathrm{C}_{3} \mathrm{H}_{8}, \mathrm{C}_{4} \mathrm{H}_{8}\right.$, i- $\mathrm{C}_{4} \mathrm{H}_{10}$, and $\mathrm{n}-\mathrm{C}_{4} \mathrm{H}_{10}$ ) encapsulated in various water cages (D, ID, T, P, H, and I) that represent the cavities of crystal gas hydrates are studied using molecular quantum-chemical computations. To explore the thermodynamic stabilities and optimal guest-cavity combinations in NGHs, the cohesive and host-guest interaction energies, enthalpies and Gibbs free energies of various water cages occupied by guest molecules are computed. To investigate the spectral characteristics of the guest-cavity systems, Raman spectra of the $\mathrm{C}-\mathrm{C}$ stretching vibrational modes of guest molecules in various water cages are simulated.

\section{COMPUTATIONAL DETAILS}

The molecular structures of various water cages (Figure 2) are obtained from the crystalline structures of $\mathrm{sI}^{57} \mathrm{sII},{ }^{58} \mathrm{sH}^{59}$ and $\mathrm{sK}^{7}$ To obtain a likely most stable structure of the empty water cage, we adjusted the arrangement of the hydrogen atoms to minimize the number of the nearest neighbor pairs that both have a dangling H-bond as in Refs. ${ }^{55,60}$. The number of nearest neighbor pairs that both have a free hydrogen atom was then $3,2,3,4,4$, and 5 for the D, ID, T, P, H, and I cage, 
respectively. In this way the unreasonable deformations of the water cage are avoided, even without the cage any occupation.

The guest molecules $\left(\mathrm{CH}_{4}, \mathrm{C}_{2} \mathrm{H}_{6}, \mathrm{C}_{3} \mathrm{H}_{6}, \mathrm{C}_{3} \mathrm{H}_{8}, \mathrm{C}_{4} \mathrm{H}_{8}, \mathrm{i}-\mathrm{C}_{4} \mathrm{H}_{10}\right.$, and $\left.\mathrm{n}-\mathrm{C}_{4} \mathrm{H}_{10}\right)$ are initially put at the center of each water cage, which are then allowed to adjust to a local-minimum orientation in the water cage through molecular mechanics optimization using the $\mathrm{CVFF}^{61}$ force field with the water cage frozen. This gives an initial rough estimate of the structure. Subsequently, the whole clusters are fully relaxed utilizing the quantum-chemical dispersion-corrected $\omega \mathrm{B} 97 \mathrm{X}-\mathrm{D}^{62}$ density functional together with the $6-311++\mathrm{G}(2 \mathrm{~d}, 2 \mathrm{p})$ basis set ${ }^{63}$, which has been found to be an appropriate computational scheme. ${ }^{39}$ The Gaussion09 program $^{64}$ was used. For the case of $\mathrm{n}-\mathrm{C}_{4} \mathrm{H}_{10}$, the molecule adopts the gauche conformations in the $\mathrm{T}$ and $\mathrm{H}$ cages and the trans conformation in the $\mathrm{P}$ and $\mathrm{I}$ cages as a result of the geometry optimizations. The energies $E$ (i.e. the electronic energies or the potential energies for the nuclear motion), and by a normal-mode computation enthalpies $H$ (which includes vibrational zero-point energies and thermal vibrational and rotational contributions) and Gibbs free energies $G$ (which includes entropic effects), are calculated for the geometry-optimized structures using the same level of theory. The host-guest interaction energies, enthalpies and Gibbs free energies, and the cohesive energies, enthalpies and Gibbs free energies per water molecule are calculated using the following expressions:

$$
\begin{aligned}
& \Delta X_{\text {host-guest }}=X_{\text {total }}-\left(X_{\text {cage }}+X_{\text {guest }}\right) \\
& \Delta X_{\text {coh }}=\frac{X_{\text {total }}-\left(n \cdot X_{\mathrm{H}_{2} \mathrm{O}}+X_{\text {guest }}\right)}{n}
\end{aligned}
$$

where $X=E, H$, or $G$. $X_{\text {total }}$ is the energy (or enthalpy or Gibbs free energy) of the water cage encapsulated with a guest molecule, $X_{\text {cage }}$ is the energy (or enthalpy or Gibbs free energy) of a corresponding empty water cage, $X_{\text {guest }}$ is the energy of an isolated guest molecule, $X_{H 2 O}$ is energy of a free water molecule, and $n$ is the number of water molecules building up the water cage. To study the effect of zero point vibrational energy, the zero point energy (ZPE) correction is explicitly computed. In the calculation of $H$ and $G$ the temperature and pressure were set to $273 \mathrm{~K}$ and 77 bar, parameters that are typical of the experimental condition ${ }^{13,27}$ Note that, since molecular cluster models are used, the pressure only enters into the calculation of the entropies, i.e. the geometry-optimized structures and $E$ and $H$ are unaffected by the pressure (which has not always been recognized in earlier studies). However, in this study we are mainly interested in the effects that can be attributed to the interactions of the guest molecules with the water molecules in the wall of cavities, whereas lattice and pressure effects (studied by periodic computations) $a^{45}$ and will be the subject of other studies.

The radius of each geometry-optimized water cage is calculated by the summation of the distances of the oxygen atoms from the center of mass of the water cage divided by the number of oxygen atoms.

Raman spectra of guest molecules trapped in various water cages are also 
modeled. In this article, the C-C stretching vibrational modes are extracted based on the contributions from the vibrational amplitudes of the carbon atoms to each normal mode, in a similar way as in previous work. ${ }^{65-66}$ When comparing with the available experimental results, ${ }^{1,} 19$ the theoretical results were found to systematically overestimate the vibrational frequencies by $10-20 \mathrm{~cm}^{-1}$. This is probably due both to deficiencies in the electronic-structure level of theory used and to the neglect of anharmonicity, since the harmonic approximation is inherent in the normal-mode calculations. Thus, as listed in Table 2, we scale the computed wavenumbers by multiplication by a scaling factor $c(0.983)$, which was obtained from a least-squares fit corresponding to the following formula ${ }^{67}$ :

$$
c=\frac{\sum v_{i} \times \omega_{i}}{\sum \omega_{i}{ }^{2}}
$$

where $v_{i}$ is the experimentally measured wavenumber and $\omega_{i}$ is the computed wavenumber from the present work. It is interesting to note that multiplication with this single factor is sufficient to bring all eight frequencies present in Table 2 into very nice agreement with experiment.

\section{RESULTS AND DISCUSSION}

\section{A. Structures and stabilities}

a) Position and dangling H-bond effects.

When a molecule is placed in one of the cavities, in general many alternative local-minimal energy positions are possible. In Figure 3a, the energy of a guest molecule enclosed at different positions in the water cages is studied. Methane or ethane molecule is put at several initial positions in the $\mathrm{D}, \mathrm{T}, \mathrm{P}$, and $\mathrm{H}$ cages, and the structure is then fully relaxed. The cohesive energies per water molecule of these clusters are calculated, which are shown in Figure 3 and in Table S1 in the supplementary material. For methane located at different positions, the largest difference of $\Delta E_{\text {coh }}$ in the $\mathrm{D}, \mathrm{T}$ and $\mathrm{P}$ cages is $0.02 \mathrm{kcal} / \mathrm{mol}$. For ethane, the largest differences in total cohesive energies for three different positions in the $\mathrm{T}$ and $\mathrm{H}$ cages are 0.02 and $0.01 \mathrm{kcal} / \mathrm{mol}$. The slight energy differences among different local minimums suggest that the potential surface is very flat. The energy is rather insensitive to the position of the guest molecule in the water cages.

The influence of the arrangement of the H-bond network, especially the number of neighboring dangling $\mathrm{H}$-bond pairs in the water cage, is also investigated in this work. As shown in Figure 4, four types of $5^{12}$ cages (D, D-Ci, D-C5, and D-S10 from Refs. 55, 56, and $\left.66 .{ }^{55-56,66}\right)$ and two types of $5^{12} 6^{4}$ cages $\left(\mathrm{H}\right.$ and $\left.\mathrm{H}^{\prime}\right)$ with different $\mathrm{H}$-bond arrangements are investigated. The number of nearest neighbor pairs that both have a free hydrogen atom is 3, 4, 5, and 10 for the D, D-Ci, D-C5, and D-S10 cage, respectively. In the $\mathrm{H}$ and the $\mathrm{H}^{\prime}$ cage there are 4 and 9 pairs, respectively. The $\mathrm{D}$ and $\mathrm{H}$ cages have the least number of nearest neighbor dangling $\mathrm{H}$-bond pairs. From Figure $3 b$ and Table $\mathrm{S} 2$, one can see that $\mathrm{CH}_{4} @ \mathrm{D}$ is much more stable than the other 
cases, and the energy difference between $\mathrm{CH}_{4} @ \mathrm{D}$ and $\mathrm{CH}_{4} @ \mathrm{D}-\mathrm{S} 10$ is $1.06 \mathrm{kcal} / \mathrm{mol}$ per water molecule; $\mathrm{C}_{2} \mathrm{H}_{6} @ \mathrm{H}$ is more stable than $\mathrm{C}_{2} \mathrm{H}_{6} @ \mathrm{H}^{\prime}$ by $0.58 \mathrm{kcal} / \mathrm{mol}$ per water molecule, and $\mathrm{H}$ is more stable than $\mathrm{H}^{\prime}$ by $0.30 \mathrm{kcal} / \mathrm{mol}$ per water molecule. Furthermore, $\mathrm{C}_{2} \mathrm{H}_{6} @ \mathrm{H}^{\prime}$ and $\mathrm{H}^{\prime}$ collapsed after optimization (see Figure 4g). It is difficult to compare with results from other studies since the quantum-chemical methods used differ and since usually detailed structures (from which the number of dangling H-bond neighbors can be deduced) are not reported, but at least for the D cage the energy was given as a function of the number of dangling $\mathrm{H}$-bond neighbors in Ref. 55 and its cohesive energy for different H-bond topologies was discussed in Ref. 56 and in Ref. 66, where the energy difference between D and D-S10 was found to be $1.24 \mathrm{kcal} / \mathrm{mol}$. The effect of the topology of the H-bond network is quite substantial, which needs to be considered in calculations of this type. ${ }^{55-56,60,66,68}$

b) O-O distances and water cavity radii.

As listed in Table 3, the average distance of the nearest neighboring O-O pairs of the empty water cages is $2.76 \AA$, which is consistent with the location of the first peak in the $\mathrm{O}-\mathrm{O}$ radical distribution function in MD simulations, ${ }^{37,69-70}$ and also in line with reported values by single-crystal diffraction studies. ${ }^{71}$ After filling the cages with the guest molecules, the geometrical parameters of the water cages will vary depending on the size and shape of the guest molecules. Every cage shrinks after encapsulating a methane molecule which is reflected by the average nearest $\mathrm{O}-\mathrm{O}$ pair distance decreasing from $2.76 \AA$ to $2.75 \AA$ and the radius of each water cage shrinking by 0.01 $\AA$ A or less.

For $\mathrm{C}_{2} \mathrm{H}_{6}$, the $\mathrm{D}$ and ID cages expand slightly and the remaining four cages shrink: the average nearest $\mathrm{O}-\mathrm{O}$ pair distances for the $\mathrm{D}$ and ID cages change from $2.76 \AA$ to $2.77 \AA$ and for the T, P, H, and I cages from $2.76 \AA$ to $2.75 \AA$. The radii of the $\mathrm{D}$ and ID cages increase by $0.02 \AA$ and $0.01 \AA$, respectively, and that of the T, P, H, and I cages shrink by $0.01-0.02 \AA$. For $\mathrm{C}_{3} \mathrm{H}_{6}$, the distance for the D and ID cages increase by $0.03 \AA$ and that of the remaining four cages decrease by $0.01 \AA$. The variations of the cavity radii show the same trend as for $\mathrm{CH}_{4}$, i.e. the $\mathrm{D}$ and ID cages expand and the T, P, H, and I cages shrink.

After encapsulating $\mathrm{C}_{3} \mathrm{H}_{8}$, the $\mathrm{D}$ and ID cages expand, the $\mathrm{T}$ cage size is unaltered, and the $\mathrm{P}, \mathrm{H}$ and I cages shrink. The nearest neighbor pair distance in the $\mathrm{D}$ and ID cages increase by $0.07 \AA$ and $0.05 \AA$, respectively, that of T cage is unaltered at 2.76 $\AA$, and that of the $\mathrm{P}, \mathrm{H}$, and I cages decrease by $0.01 \AA$. In addition, the cavity radii follow the same pattern.

The above-mentioned results can be rationalized by comparison with experiment. The ratios of molecular diameter of methane to the cavity diameter are 0.855 (in sI, 0.868 in sII), 0.744 , and 0.652 for the $\mathrm{D}, \mathrm{T}$, and $\mathrm{H}$ cages, respectively. ${ }^{2}$ Thus, the cavities will shrink after inclusion of a methane molecule. For ethane, the ratios of molecular to cavity diameter are 1.08 (in sI, 1.10 in sII), 0.939 , and 0.826 for the $\mathrm{D}, \mathrm{T}$, and $\mathrm{H}$ cavities, respectively. ${ }^{2}$ Therefore, the $\mathrm{D}$ cage expands and the $\mathrm{T}$ and $\mathrm{H}$ cage shrink after encapsulating $\mathrm{C}_{2} \mathrm{H}_{6}$ in each cage. $\mathrm{C}_{3} \mathrm{H}_{8}$ follows the same trend, the ratio of guest molecular diameter to the cavity diameter is much greater than 1.0 for the $\mathrm{D}$ 
cage (1.23), ${ }^{2}$ thus it expands after including propane. However, that of the $\mathrm{H}$ cage is 0.943 , thus it shrinks after $\mathrm{C}_{3} \mathrm{H}_{8}$ occupation in agreement with what is observed here.

The guests $\mathrm{C}_{4} \mathrm{H}_{8}, \quad \mathrm{i}-\mathrm{C}_{4} \mathrm{H}_{10}$ and $\mathrm{n}-\mathrm{C}_{4} \mathrm{H}_{10}$ also show the same trend: after encapsulation where the ratio of the molecular diameter to the cavity diameter is less than 1.0 the cage will shrink, as shown by the $\mathrm{O}-\mathrm{O}$ distances and the water cage radii decreasing; conversely, if the ratio is greater than 1.0 the cavity will expand.

c) Host-guest interaction and cohesive energies.

In NGHs system, the interactions between host water cavity walls and guest molecules and the interactions among the water molecules are among the factors which determine the stability of the clathrate lattice. The $\Delta E_{\text {host-guest }}$ is dominated by the van der Waal (vdW) interaction between the guest molecule and the water cavity wall. $\Delta E_{\text {host-guest }}$ with and without ZPE correction are listed in Table 4. For the methane molecule encapsulated in a $\mathrm{D}$ cage, the $\Delta E_{\text {host-guest }}$ is $-5.5 \mathrm{kcal} / \mathrm{mol}$ and -7.2 $\mathrm{kcal} / \mathrm{mol}$ with and without ZPE correction, respectively. It is close to the result $(-6.1$ $\mathrm{kcal} / \mathrm{mol})^{40}$ from MP2/CBS calculations after including the ZPE correction. The ZPE effect for $\mathrm{CH}_{4}$ encapsulated in each cavity is between $10 \%$ and $27 \%$ of $\Delta E_{\text {host-guest. If }}$ we consider all the cases, the ZPE of $\Delta E_{\text {host-guest }}$ is between $5 \%$ and $54 \%$, except for $\mathrm{C}_{3} \mathrm{H}_{8}$ and $\mathrm{C}_{4} \mathrm{H}_{8}$ encapsulated in the $\mathrm{D}$ cage. For $\mathrm{C}_{3} \mathrm{H}_{8}$ and $\mathrm{C}_{4} \mathrm{H}_{8}$ encapsulated in the $\mathrm{D}$ cage, the interaction is attractive without ZPE correction; however, it becomes repulsive after including the ZPE correction. Furthermore, the ZPE of $\Delta E_{c o h}$ is between $24 \%$ and $26 \%$ for all cases listed in Table 5 . Thus, the ZPE effect is quite significant when computing $\Delta E_{\text {host-guest }}$ and $\Delta E_{\text {coh }}$.

In Figure 5, the $\Delta E_{\text {host-guest }}$ with ZPE correction for different guest molecules encapsulated in different water cavities is depicted. The interaction is the strongest for methane encapsulated in the D or the ID cage, as the $\Delta E_{\text {host-guest }}$ of $\mathrm{CH}_{4} @ \mathrm{D}$ and $\mathrm{CH}_{4} @ \mathrm{ID}$ is lower than for the other cages. Regarding ethane, it interacts more favorably when encapsulated in a $T$ cage than in the other cages. $\mathrm{C}_{3} \mathrm{H}_{6}, \mathrm{C}_{3} \mathrm{H}_{8}$, and $\mathrm{C}_{4} \mathrm{H}_{8}$ interact most strongly with the cage when trapped in $\mathrm{P}$ cages. Both $\mathrm{i}-\mathrm{C}_{4} \mathrm{H}_{10}$ and $\mathrm{n}-\mathrm{C}_{4} \mathrm{H}_{10}$ binds the strongest in an $\mathrm{H}$ cage.

The cohesive energy $\left(\Delta E_{c o h}\right)$ contains contributions from both the cavity-guest $\mathrm{vdW}$ interactions and from the water (mainly H-bonding) interactions. As depicted in Figure 6 , the water cavity occupied by a guest molecule will be more stable than the empty cage except when the guest molecule does not fit into the cage, i.e. $\mathrm{C}_{3} \mathrm{H}_{8}$ and $\mathrm{C}_{4} \mathrm{H}_{8}$ in a $\mathrm{D}$ cage. Since the cohesive energy $\Delta E_{c o h}$ is given per number of water molecules, the stabilities of water cages with different sizes can be compared. The empty water cages have similar cohesion energies. $\mathrm{For}_{\mathrm{CH}}$, the largest stabilization is obtained when it occupies a D cage. For $\mathrm{C}_{2} \mathrm{H}_{6}, \mathrm{C}_{3} \mathrm{H}_{6}$, and $\mathrm{C}_{3} \mathrm{H}_{8}$, the maximum stabilization occurs when they are encapsulated in a $\mathrm{T}$ cage. However, very similar cohesive energy is obtained when $\mathrm{C}_{4} \mathrm{H}_{8}$ occupies a $\mathrm{T}$, $\mathrm{P}$, or an $\mathrm{H}$ cage. Finally, both $\mathrm{i}-\mathrm{C}_{4} \mathrm{H}_{10}$ and $\mathrm{n}-\mathrm{C}_{4} \mathrm{H}_{10}$ will gain the most cohesive energy when occupying an $\mathrm{H}$ cage.

d) Enthalpies and Gibbs free energies.

The reaction enthalpies of forming various water cavities encapsulated with 
hydrocarbon molecules in the NGH models at $77 \mathrm{~atm}$ and $273 \mathrm{~K}$ are shown in Figures $7 \mathrm{a}, 7 \mathrm{~b}$ and Table S3. As seen from the $\Delta H_{\text {host-guest }}$ in Figure $7 \mathrm{a}$, all the formation processes of enclathrated molecules from free guest molecules and (already formed) water cages are exothermic, except for encapsulation of $\mathrm{C}_{3} \mathrm{H}_{8}$ or $\mathrm{C}_{4} \mathrm{H}_{8}$ in a D cage. The formation of the complexes from free water molecules and a hydrocarbon molecule are all exothermic processes, as seen for $\Delta H_{c o h}$ in Figure $7 \mathrm{~b}$. Regarding the combination of a given guest molecule with different water cages, $\mathrm{CH}_{4} @ \mathrm{D}$, $\mathrm{C}_{2} \mathrm{H}_{6} / \mathrm{C}_{3} \mathrm{H}_{6} / \mathrm{C}_{3} \mathrm{H}_{8} @ \mathrm{~T}, \mathrm{C}_{4} \mathrm{H}_{8} @ \mathrm{~T}$ (or possibly P or H) and i- $\mathrm{C}_{4} \mathrm{H}_{10} / \mathrm{n}-\mathrm{C}_{4} \mathrm{H}_{10} @ \mathrm{H}$ will have the largest negative $\Delta H_{\text {coh }}$.

The changes in Gibbs free energy when water cavities are occupied by guest molecules are shown in Figure 7c, 7d and Table S4. At $77 \mathrm{~atm}$ and $273 \mathrm{~K}, \Delta G_{\text {host-guest }}$ is positive when $\mathrm{CH}_{4}$ occupies any (pre-formed) cage. However, $\mathrm{C}_{2} \mathrm{H}_{6}$ will spontaneously occupy empty $\mathrm{T}, \mathrm{P}$, and $\mathrm{H}$ cages, $\mathrm{C}_{3} \mathrm{H}_{6}$ the $\mathrm{T}, \mathrm{P}, \mathrm{H}$, and I cages, and $\mathrm{C}_{3} \mathrm{H}_{8}, \mathrm{C}_{4} \mathrm{H}_{8}, \mathrm{i}-\mathrm{C}_{4} \mathrm{H}_{10}$, and $\mathrm{n}-\mathrm{C}_{4} \mathrm{H}_{10}$ all will spontaneously occupy the empty $\mathrm{P}, \mathrm{H}$, and $\mathrm{I}$ cages), see Figure 7c. (Note that from a thermodynamic point of view all processes with $\Delta G<0$ are spontaneous, even though the rate may be low.) For the formation of the complexes from free water molecules and a free hydrocarbon molecule, the free energy change $\Delta G_{c o h}$ is negative in all cases (Figure $7 \mathrm{~d}$ ). From comparison of $\Delta G_{\text {host-guest }}$ for the same guest molecule encapsulated in different water cavities, $\mathrm{CH}_{4}$ prefer to be trapped in an $\mathrm{H}$ (or possibly $\mathrm{P}$ ) cage; $\mathrm{C}_{2} \mathrm{H}_{6}$ and $\mathrm{C}_{4} \mathrm{H}_{8}$ a $\mathrm{H}$ cage; $\mathrm{C}_{3} \mathrm{H}_{6}$ a $\mathrm{P}$ (or possibly $\mathrm{H}$ ) cage; $\mathrm{C}_{3} \mathrm{H}_{8}$ a I (or possibly $\mathrm{H}$ ) cage; i- $\mathrm{C}_{4} \mathrm{H}_{10}$ and $n-\mathrm{C}_{4} \mathrm{H}_{10}$ prefer a I cage. If the complexes are formed from isolated water molecules and hydrocarbons, the most favorable combination (lowest $\Delta G_{c o h}$ ) for each guest molecule is $\mathrm{CH}_{4} @ \mathrm{ID}$, $\mathrm{C}_{2} \mathrm{H}_{6} @ \mathrm{~T}, \mathrm{C}_{3} \mathrm{H}_{6} / \mathrm{C}_{3} \mathrm{H}_{8} @ \mathrm{~T}$ or $\mathrm{H}, \mathrm{C}_{4} \mathrm{H}_{8} / \mathrm{i}-\mathrm{C}_{4} \mathrm{H}_{10} @ \mathrm{H}$, and n- $\mathrm{C}_{4} \mathrm{H}_{10} @ \mathrm{I}$.

\section{B. Raman spectra of guest molecule C-C vibrations}

The vibrational C-C stretching frequencies of guest molecules can be used to identify the types of crystal structure of NGHs and the types of guest molecules. In this work the C-C stretching vibrational Raman spectra of hydrocarbon molecules trapped in various water cavities of NGHs are computed, see Table 6.

Shown in Figure 8a are the Raman spectra of the $\mathrm{C}-\mathrm{C}$ stretching mode of ethane encapsulated in various water cages and in the gas phase. The frequencies are red-shifted when going from the $\mathrm{D}$ cage to the $\mathrm{H}$ cage, as the radii of the water cages increases. The frequency of $\mathrm{C}_{2} \mathrm{H}_{6}$ in the I cage is almost equal to that in the gas phase. The agreement between the computed and experimental $\mathrm{C}-\mathrm{C}$ vibrational frequencies support the inference that ethane can be trapped in the small $5^{12}$ cage of the sI and sII phases. ${ }^{19}$

The vibrational spectra of $\mathrm{C}_{3} \mathrm{H}_{8}$ are presented in Figure 8b. Upon encapsulation in the water cages both the $\mathrm{A}_{1}$ and $\mathrm{B}_{2} \mathrm{C}-\mathrm{C}$ stretching mode frequencies will be blue-shifted compared to in the gas phase. As the radii of the water cavities increase the $\mathrm{C}-\mathrm{C}$ stretching frequencies will shift to the red.

For $\mathrm{C}_{3} \mathrm{H}_{6}$ and $\mathrm{C}_{4} \mathrm{H}_{8}$ the spectra are presented in Figure 9. The antisymmetric C-C stretching mode of $\mathrm{C}_{3} \mathrm{H}_{6}$ is located at the lower frequency region and the symmetric 
mode is in the higher frequency region. For $\mathrm{C}_{3} \mathrm{H}_{6}$ both of them are red-shifted when going from the smaller cages to the larger cages. For $\mathrm{C}_{4} \mathrm{H}_{8}$ in the gas phase, when as here the point group $\mathrm{D}_{2 \mathrm{~d}}$. is used, has three C-C stretching mode symmetries: E (914 $\left.\mathrm{cm}^{-1}\right), \mathrm{B}_{1}\left(947 \mathrm{~cm}^{-1}\right)$, and $\mathrm{A}_{1}\left(1015 \mathrm{~cm}^{-1}\right)$, where $\mathrm{A} 1$ is the symmetric stretching mode. The E C-C stretching vibration is very weak, thus we mainly focus on the $\mathrm{B}_{1}$ and $\mathrm{A}_{1}$ modes. Going from the smaller cages to the larger cages, both the $\mathrm{B}_{1}$ and $\mathrm{A}_{1} \mathrm{C}-\mathrm{C}$ stretching modes are red-shifted as the size of the water cage increases.

The spectra of $\mathrm{i}-\mathrm{C}_{4} \mathrm{H}_{10}$ can be seen in Figure 10. The symmetric and antisymmetric stretching modes of $\mathrm{i}-\mathrm{C}_{4} \mathrm{H}_{10}$ are located in the lower and in the higher frequency part in the spectra, respectively. In the same way as for the molecules discussed above, the red shift is also present for both the symmetric and the antisymmetric vibration when going from smaller cages to larger cages and to the gas phase.

The molecule $n-\mathrm{C}_{4} \mathrm{H}_{10}$ has two well-known isomers: trans $n-\mathrm{C}_{4} \mathrm{H}_{10}$ and gauche $\mathrm{n}-\mathrm{C}_{4} \mathrm{H}_{10}$. Whereas the trans form was obtained in the $\mathrm{P}$ and $\mathrm{I}$ cages, it transformed into the gauche form in the $\mathrm{T}$ and $\mathrm{H}$ cages This consistent with the experimental observation of the spectral features of gauche $n-\mathrm{C}_{4} \mathrm{H}_{10}$ in Raman spectra of the sII hydrate, from which it has been concluded that trans $n-\mathrm{C}_{4} \mathrm{H}_{10}$ is too large to enter the $\mathrm{H}$ cage of the sII phase. ${ }^{19,} 72$ The computed gauche $\mathrm{n}-\mathrm{C}_{4} \mathrm{H}_{10}$ C-C stretching frequencies in the range of experimental interest are at 858 (with the highest intensity), 870 (lowest intensity) and $1091 \mathrm{~cm}^{-1}$. The frequency $1091 \mathrm{~cm}^{-1}$ corresponds to a symmetric C-C stretching mode that is largely uncoupled from the motion of the water molecules, and the position is in fairly good agreement with the experimental peak position of $1082 \mathrm{~cm}^{-1} .{ }^{19}$ The computed peak at $858 \mathrm{~cm}^{-1}$ differs more from the observed peak at $839 \mathrm{~cm}^{-1}$. A visual inspection of this mode reveals that it highly coupled with the motion of the water molecules in the wall, and since the wall itself is less well described in our present model a larger discrepancy can be expected for this mode. In fact, there are also similar modes at 812,826 and $847 \mathrm{~cm}^{-1}$ of roughly half the intensity of the $858 \mathrm{~cm}^{-1}$ mode, and the intensity-weighted average of these four modes is at $842 \mathrm{~cm}^{-1}$, which is in considerably better agreement with the experimental value at $839 \mathrm{~cm}^{-1} \cdot{ }^{19}$ All in all, the computations support the conclusion from experiment that $\mathrm{n}-\mathrm{C}_{4} \mathrm{H}_{10}$ is present in the gauche form in $\mathrm{H}$ cages. ${ }^{19}$

The trans $n-\mathrm{C}_{4} \mathrm{H}_{10}$ molecule in gas phase is of $\mathrm{C}_{2 \mathrm{~h}}$ symmetry. In comparison with the frequencies in the gas phase, the frequencies of the guest molecules in the $\mathrm{P}$ and $\mathrm{I}$ cages are blue-shifted in both cases. The $\mathrm{C}-\mathrm{C}$ stretching frequencies are also for both forms of $n-\mathrm{C}_{4} \mathrm{H}_{10}$ red-shifted as the water cavity radius increases.

\section{CONCLUSIONS}

The thermodynamic stabilities and vibrational spectra of various water cavities occupied by different guest molecules typically present in NGHs have been investigated by molecular quantum-chemical computations. The interaction energy is insensitive to the different local-minimal possibilities within the cavity, but the arrangement of dangling H-bonds of the water cage is significant. The ZPE effect of 
$\Delta E_{\text {host-guest }}$ and $\Delta E_{\text {coh }}$ is substantial.

The cavity will shrink if occupied by a small molecule (the ratio of molecular diameter to cavity diameter less than 1.0); if occupied by a large molecule (ratio greater than 1.0), both the average $\mathrm{O}-\mathrm{O}$ distance and the radius of the cavity will increase. The energetically optimal host-guest combinations among these seven hydrocarbon gas molecules in various water cavities in NGHs are $\mathrm{CH}_{4} @ \mathrm{D}, \mathrm{C}_{2} \mathrm{H}_{6} @ \mathrm{~T}$, $\mathrm{C}_{3} \mathrm{H}_{6} @ \mathrm{~T}, \mathrm{C}_{3} \mathrm{H}_{8} @ \mathrm{~T}, \mathrm{C}_{4} \mathrm{H}_{8} @ \mathrm{~T}$ (or possibly P or H), i- $\mathrm{C}_{4} \mathrm{H}_{10} @ \mathrm{H}$, and n- $\mathrm{C}_{4} \mathrm{H}_{10} @ \mathrm{H}$, from the point of view that the largest magnitudes of cohesive energies will be obtained with these host-guest combinations. From the cohesive free energies $\left(\Delta G_{c o h}\right)$ the most favorable combination for each guest molecule is $\mathrm{CH}_{4} @ \mathrm{ID}, \mathrm{C}_{2} \mathrm{H}_{6} @ \mathrm{~T}, \mathrm{C}_{3} \mathrm{H}_{6} / \mathrm{C}_{3} \mathrm{H}_{8} @ \mathrm{~T}$ or $\mathrm{H}, \mathrm{C}_{4} \mathrm{H}_{8} / \mathrm{i}-\mathrm{C}_{4} \mathrm{H}_{10} @ \mathrm{H}$, and n- $\mathrm{C}_{4} \mathrm{H}_{10} @ \mathrm{I}$.

The $\mathrm{C}-\mathrm{C}$ stretching vibrational frequencies of these seven hydrocarbon molecules enclosed in the different water cavities have been computed. There will be a blue shift after the guest molecule is trapped from the gas phase into various water cages, due to the host-guest interactions between water cages and hydrocarbon molecules. The frequencies will shift to the red as the radius of water cages increases. The computations indicate that $\mathrm{n}-\mathrm{C}_{4} \mathrm{H}_{10}$ is present in the gauche conformation in $\mathrm{T}$ and $\mathrm{H}$ cages, which has been previously concluded from experiment for $\mathrm{H}$ cages in sII hydrates. ${ }^{19}$

The computed trends of the C-C stretching vibrations of hydrocarbon molecules in the water cages can possibly be used to help identify the types of crystal phases and guest molecules in NGHs. Similarly, the C-H stretching vibration of guest molecules in clathrate hydrates can also be used to provide information about the crystal phases and guest molecules; this will be the focus of a forthcoming paper.

\section{ACKNOWLEDGMENTS}

This work is supported by the Swedish Research Council (VR), the Swedish supercomputer center (NSC), and a scholarship under the State Scholarship Fund of China Scholarship Council (File No. 201206060016). 


\section{REFERENCES}

1. Sloan, E. D.; koh, C. A., Clathrate Hydrates of Natural Gases. Third ed.; CRC Press/Taylor\&Francis Group: Boca Raton: 2008.

2. Sloan, E. D., Fundamental principles and applications of natural gas hydrates. Nature 2003, 426, 353-359.

3. Sum, A. K.; Koh, C. A.; Sloan, E. D., Clathrate Hydrates: From Laboratory Science to Engineering Practice. Ind. Eng. Chem. Res. 2009, 48, 7457-7465.

4. Koh, C. A.; Sum, A. K.; Sloan, E. D., Gas hydrates: Unlocking the energy from icy cages. J. Appl. Phys. 2009, 106, 061101.

5. Goldschleger, I. U.; Kerenskaya, G.; Janda, K. C.; Apkarian, V. A., Polymorphism in Br-2 clathrate hydrates. J. Phys. Chem. A 2008, 112, 787-789.

6. Yang, L.; Tulk, C. A.; Klug, D. D.; Moudrakovski, I. L.; Ratcliffe, C. I.; Ripmeester, J. A.; Chakoumakos, B. C.; Ehm, L.; Martin, C. D.; Parise, J. B., Synthesis and characterization of a new structure of gas hydrate. Proc. Natl. Acad. Sci. USA/PNAS 2009, 106, 6060-6064.

7. Vatamanu, J.; Kusalik, P. G., Unusual crystalline and polycrystalline structures in methane hydrates. J. Am. Chem. Soc. 2006, 128, 15588-15589.

8. $\quad$ Loveday, J. S.; Nelmes, R. J.; Guthrie, M.; Belmonte, S. A.; Allan, D. R.; Klug, D. D.; Tse, J. S.; Handa, Y. P., Stable methane hydrate above $2 \mathrm{GPa}$ and the source of Titan's atmospheric methane. Nature 2001, 410, 661-663.

9. Loveday, J. S.; Nelmes, R. J.; Guthrie, M.; Klug, D. D.; Tse, J. S., Transition from cage clathrate to filled ice: The structure of methane hydrate III. Phys. Rev. Lett. 2001, 87, 215501.

10. Vos, W. L.; Finger, L. W.; Hemley, R. J.; Mao, H. K., Novel $\mathrm{H}_{2}-\mathrm{H}_{2} \mathrm{O}$ clathrates at high-pressures. Phys. Rev. Lett. 1993, 71, 3150-3153.

11. Koh, C. A., Towards a fundamental understanding of natural gas hydrates. Chem. Soc. Rev. 2002, 31, 157-167.

12. Hansen, S. B.; Berg, R. W., Raman Spectroscopic Studies of Methane Gas Hydrates. Appl. Spec. Rev. 2009, 44, 168-179.

13. Hester, K. C.; White, S. N.; Peltzer, E. T.; Brewer, P. G.; Sloan, E. D., Raman spectroscopic measurements of synthetic gas hydrates in the ocean. Marine Chem. 2006, 98, 304-314.

14. Liu, C. L.; Lu, H. L.; Ye, Y. G.; Ripmeester, J. A.; Zhang, X. H., Raman Spectroscopic Observations on the Structural Characteristics and Dissociation Behavior of Methane Hydrate Synthesized in Silica Sands with Various Sizes. Energy Fuels 2008, 22, 3986-3988.

15. Schicks, J. M.; Naumann, R.; Erzinger, J.; Hester, K. C.; Koh, C. A.; Sloan, E. D., Phase transitions in mixed gas hydrates: Experimental observations versus calculated data. J. Phys. Chem. B 2006, 110, 11468-11474.

16. Guo, G. J.; Zhang, Y. G.; Zhao, Y. J.; Refson, K.; Shan, G. H., Lifetimes of cagelike water clusters immersed in bulk liquid water: A molecular dynamics study on gas hydrate nucleation mechanisms. $J$. Chem. Phys. 2004, 121, 1542-1547.

17. Liang, S.; Kusalik, P. G., Explorations of gas hydrate crystal growth by molecular simulations. Chem. Phys. Lett. 2010, 494, 123-133.

18. Cao, X. X.; Su, Y.; Zhao, J. J.; Liu, C. L.; Zhou, P. W., Stability and Raman Spectroscopy of Alkane Guest Molecules $\left(\mathrm{C}_{\mathrm{n}} \mathrm{H}_{\mathrm{m}}, \mathrm{n} \leq 6, \mathrm{~m} \leq 14\right)$ in $5^{12} 6^{2}$ and $5^{12} 6^{4}$ Water Cavities by Density Functional Theory Calculations. Acta. Phys-Chim. Sin. 2014, 30, 1437-1446. 
19. Subramanian, S.; Sloan, E. D., Trends in vibrational frequencies of guests trapped in clathrate hydrate cages. J. Phys. Chem. B 2002, 106, 4348-4355.

20. Subramanian, S.; Kini, R. A.; Dec, S. F.; Sloan, E. D., Evidence of structure II hydrate formation from methane plus ethane mixtures. Chemical Engineering Science 2000, 55, 1981-1999.

21. Sum, A. K.; Burruss, R. C.; Sloan, E. D., Measurement of clathrate hydrates via Raman spectroscopy. J. Phys. Chem. B 1997, 101, 7371-7377.

22. Uchida, T.; Hirano, T.; Ebinuma, T.; Narita, H.; Gohara, K.; Mae, S.; Matsumoto, R., Raman spectroscopic determination of hydration number of methane hydrates. Aiche Journal 1999, 45, 2641-2645.

23. Subramanian, S.; Sloan, E. D., Microscopic measurements and modeling of hydrate formation kinetics. In Gas Hydrates: Challenges for the Future, Holder, G. D.; Bishnoi, P. R., Eds. 2000; Vol. 912, pp 583-592.

24. Murshed, M. M.; Kuhs, W. F., Kinetic Studies of Methane-Ethane Mixed Gas Hydrates by Neutron Diffraction and Raman Spectroscopy. J. Phys. Chem. B 2009, 113, 5172-5180.

25. Uchida, T.; Takeya, S.; Kamata, Y.; Ikeda, I. Y.; Nagao, J.; Ebinuma, T.; Narita, H.; Zatsepina, O.; Buffett, B. A., Spectroscopic observations and thermodynamic calculations on clathrate hydrates of mixed gas containing methane and ethane: Determination of structure, composition and cage occupancy. J. Phys. Chem. B 2002, 106, 12426-12431.

26. Chazallon, B.; Focsa, C.; Charlou, J. L.; Bourry, C.; Donval, J. P., A comparative Raman spectroscopic study of natural gas hydrates collected at different geological sites. Chem. Geol. 2007, $244,175-185$

27. Hester, K. C.; Dunk, R. M.; White, S. N.; Brewer, P. G.; Peltzer, E. T.; Sloan, E. D., Gas hydrate measurements at Hydrate Ridge using Raman spectroscopy. Geochim. Cosmochim. Ac. 2007, 71, 2947-2959.

28. Liang, S.; Kusalik, P. G., The Mobility of Water Molecules through Gas Hydrates. J. Am. Chem. Soc. 2011, 133, 1870-1876.

29. Tung, Y. T.; Chen, L. J.; Chen, Y. P.; Lin, S. T., The Growth of Structure I Methane Hydrate from Molecular Dynamics Simulations. J. Phys. Chem. B 2010, 114, 10804-10813.

30. Tang, L. L.; Su, Y.; Liu, Y.; Zhao, J. J.; Qiu, R. F., Nonstandard cages in the formation process of methane clathrate: Stability, structure, and spectroscopic implications from first-principles. J. Chem. Phys. 2012, 136, 224508.

31. Cao, X. X.; Su, Y.; Liu, Y.; Zhao, J. J.; Liu, C. L., Storage Capacity and Vibration Frequencies of Guest Molecules in $\mathrm{CH}_{4}$ and $\mathrm{CO}_{2}$ Hydrates by First-Principles Calculations. J. Phys. Chem. A 2014, $118,215-222$.

32. Guo, G. J.; Zhang, Y. G.; Li, M.; Wu, C. H., Can the dodecahedral water cluster naturally form in methane aqueous solutions? A molecular dynamics study on the hydrate nucleation mechanisms. $J$. Chem. Phys. 2008, 128.

33. Guo, G. J.; Li, M.; Zhang, Y. G.; Wu, C. H., Why can water cages adsorb aqueous methane? A potential of mean force calculation on hydrate nucleation mechanisms. Phys. Chem. Chem. Phys. 2009, $11,10427-10437$.

34. Jacobson, L. C.; Hujo, W.; Molinero, V., Amorphous Precursors in the Nucleation of Clathrate Hydrates. J. Am. Chem. Soc. 2010, 132, 11806-11811.

35. Vatamanu, J.; Kusalik, P. G., Observation of two-step nucleation in methane hydrates. Phys. Chem. Chem. Phys. 2010, 12, 15065-15072. 
36. Walsh, M. R.; Koh, C. A.; Sloan, E. D.; Sum, A. K.; Wu, D. T., Microsecond Simulations of Spontaneous Methane Hydrate Nucleation and Growth. Science 2009, 326, 1095-1098.

37. Liu, Y.; Zhao, J. J.; Xu, J. C., Dissociation mechanism of carbon dioxide hydrate by molecular dynamic simulation and ab initio calculation. Comput. Theor. Chem. 2012, 991, 165-173.

38. Huang, Y.; Liu, Y.; Su, Y.; Zhao, J., Dissociation mechanism of gas hydrates (I, II, H) of alkane molecules: a comparative molecular dynamics simulation. Mol. Simulat. 2014.

39. Liu, Y.; Zhao, J. J.; Li, F. Y.; Chen, Z. F., Appropriate description of intermolecular interactions in the methane hydrates: An assessment of DFT methods. J. Comput. Chem. 2013, 34, 121-131.

40. Kumar, P.; Sathyamurthy, N., Theoretical Studies of Host-Guest Interaction in Gas Hydrates. $J$. Phys. Chem. A 2011, 115, 14276-14281.

41. Ramya, K. R.; Venkatnathan, A., Stability and Reactivity of Methane Clathrate Hydrates: Insights from Density Functional Theory. J. Phys. Chem. A 2012, 116, 7742-7745.

42. Li, Q.; Kolb, B.; Roman-Perez, G.; Soler, J. M.; Yndurain, F.; Kong, L. Z.; Langreth, D. C.; Thonhauser, T., Ab initio energetics and kinetics study of $\mathrm{H}_{2}$ and $\mathrm{CH}_{4}$ in the SI clathrate hydrate. Phys. Rev. B 2011, 84, 153103.

43. Roman-Perez, G.; Moaied, M.; Soler, J. M.; Yndurain, F., Stability, Adsorption, and Diffusion of $\mathrm{CH}_{4}, \mathrm{CO}_{2}$, and $\mathrm{H}_{2}$ in Clathrate Hydrates. Phys. Rev. Lett. 2010, 105, 145901.

44. Patchkovskii, S.; Tse, J. S., Thermodynamic stability of hydrogen clathrates. Proc. Natl. Acad. Sci. USA/PNAS 2003, 100, 14645-14650.

45. Lenz, A.; Ojamäe, L., Structures of the I-, II- and H-Methane Clathrates and the Ice-Methane Clathrate Phase Transition from Quantum-Chemical Modeling with Force-Field Thermal Corrections. $J$. Phys. Chem. A 2011, 115, 6169-6176.

46. Ikeda, T.; Terakura, K., Structural transformation of methane hydrate from cage clathrate to filled ice. J. Chem. Phys. 2003, 119, 6784-6788.

47. Tse, J. S., Vibrations of Methane in Structure I Clathrate Hydrate - an ab initio Density Functional Molecular Dynamics Study. J. Supramol. Chem. 2002, 2, 429.

48. Hiratsuka, M.; Ohmura, R.; Sum, A. K.; Yasuoka, K., Molecular vibrations of methane molecules in the structure I clathrate hydrate from ab initio molecular dynamics simulation. J. Chem. Phys. 2012, $136,044508$.

49. Ramya, K. R.; Kumar, G. V. P.; Venkatnathan, A., Raman spectra of vibrational and librational modes in methane clathrate hydrates using density functional theory. J. Chem. Phys. 2012, 136, 174305.

50. Siuda, P.; Sadlej, J., Nuclear Magnetic Resonance Parameters for Methane Molecule Trapped in Clathrate Hydrates. J. Phys. Chem. A 2011, 115, 612-619.

51. Siuda, P.; Sadlej, J., Calculations of NMR properties for sI and sII clathrate hydrates of carbon dioxide. Chemical Physics 2014, 433, 31-41.

52. Ida, T.; Mizuno, M.; Endo, K., Electronic state of small and large cavities for methane hydrate. $J$. Comput. Chem. 2002, 23, 1071-1075.

53. Srivastava, H. K.; Sastry, G. N., Viability of Clathrate Hydrates as $\mathrm{CO}_{2}$ Capturing Agents: A Theoretical Study. J. Phys. Chem. A 2011, 115, 7633-7637.

54. Chattaraj, P. K.; Bandaru, S.; Mondal, S., Hydrogen Storage in Clathrate Hydrates. J. Phys. Chem. A 2011, 115, 187-193.

55. McDonald, S.; Ojamäe, L.; Singer, S. J., Graph theoretical generation and analysis of hydrogen-bonded structures with applications to the neutral and protonated water cube and 
dodecahedral clusters. J. Phys. Chem. A 1998, 102, 2824-2832.

56. Kuo, J. L.; Ciobanu, C. V.; Ojamäe, L.; Shavitt, I.; Singer, S. J., Short H-bonds and spontaneous self-dissociation in $\left(\mathrm{H}_{2} \mathrm{O}\right)_{20}$ : Effects of H-bond topology. J. Chem. Phys. 2003, 118, 3583-3588.

57. Gutt, C.; Asmussen, B.; Press, W.; Johnson, M. R.; Handa, Y. P.; Tse, J. S., The structure of deuterated methane-hydrate. J. Chem. Phys. 2000, 113, 4713-4721.

58. Rawn, C. J.; Rondinone, A. J.; Chakoumakos, B. C.; Circone, S.; Stern, L. A.; Kirby, S. H.; Ishii, Y., Neutron powder diffraction studies as a function of temperature of structure II hydrate formed from propane. Can. J. Phys. 2003, 81, 431-438.

59. Udachin, K. A.; Ratcliffe, C. I.; Enright, G. D.; Ripmeester, J. A., Structure H Hydrate: A Single Crystal Diffraction Study of 2,2-dimethylpentane-5(Xe, $\left.\mathrm{H}_{2} \mathrm{~S}\right) \cdot 34 \mathrm{H}_{2} \mathrm{O}$. Supramol. Chem. 1997, 8, 173-176.

60. Lenz, A.; Ojamäe, L., A theoretical study of water clusters: the relation between hydrogen-bond topology and interaction energy from quantum-chemical computations for clusters with up to 22 molecules. Phys. Chem. Chem. Phys. 2005, 7, 1905-1911.

61. Lawson, C. L.; Zhang, R. G.; Schevitz, R. W.; Otwinowski, Z.; Joachimiak, A.; Sigler, P. B., Flexibility of the DNA-binding domains of trp repressor. Protein-Struct. Funct. Genet. 1988, 3, 18-31.

62. Chai, J. D.; Head-Gordon, M., Long-range corrected hybrid density functionals with damped atom-atom dispersion corrections. Phys. Chem. Chem. Phys. 2008, 10, 6615-6620.

63. Hehre, W. J.; Ditchfield, R.; Pople, J. A., Self-Consistent Molecular Orbital Methods. XII. Further Extensions of Gaussian-Type Basis Sets for Use in Molecular Orbital Studies of Organic Molecules. J. Chem. Phys. 1972, 56, 2257.

64. Frisch, M. J.; Trucks, G. W.; Schlegel, H. B. Gaussian 09, Gaussion Inc.: Wallingford CT, 2011.

65. Liu, Y.; Ojamäe, L., Fingerprints in IR $\mathrm{OH}$ vibrational spectra of $\mathrm{H}_{2} \mathrm{O}$ clusters from different H-bond conformations by means of quantum-chemical computations. J. Mol. Model. 2014, 20, 2281.

66. Lenz, A.; Ojamäe, L., Theoretical IR spectra for water clusters $\left(\mathrm{H}_{2} \mathrm{O}\right)_{n}(\mathrm{n}=6-22,28,30)$ and identification of spectral contributions from different $\mathrm{H}$-bond conformations in gaseous and liquid water. J. Phys. Chem. A 2006, 110, 13388-13393.

67. Irikura, K. K.; Johnson, R. D.; Kacker, R. N., Uncertainties in scaling factors for ab initio vibrational frequencies. J. Phys. Chem. A 2005, 109, 8430-8437.

68. Kuo, J. L.; Coe, J. V.; Singer, S. J.; Band, Y. B.; Ojamäe, L., On the use of graph invariants for efficiently generating hydrogen bond topologies and predicting physical properties of water clusters and ice. J. Chem. Phys. 2001, 114, 2527-2540.

69. Ding, L. Y.; Geng, C. Y.; Zhao, Y. H.; Wen, H., Molecular dynamics simulation on the dissociation process of methane hydrates. Mol. Simulat. 2007, 33, 1005-1016.

70. Ota, M.; Ferdows, M., Monte Carlo approach to structure and thermodynamic property of $\mathrm{CO}_{2}$ hydrate. JSME Int J., Ser. B 2005, 48, 802-809.

71. Kirchner, M. T.; Boese, R.; Billups, W. E.; Norman, L. R., Gas hydrate single-crystal structure analyses. J. Am. Chem. Soc. 2004, 126, 9407-9412.

72. Davidson, S. W.; Garg, S. K.; Gough, S. R.; Hawkins, R. E.; Ripmeester, J. A., Characterization of natural gas hydrates by nuclear magnetic resonance and dielectric relaxation Canadian Journal of Chemistry-Revue Canadienne De Chimie 1977, 55, 3641-3650. 
Table 1. Structural properties for the cavities in different crystal phases of hydrates.

\begin{tabular}{|c|c|c|c|c|c|c|c|c|c|c|}
\hline Crystal phase & \multicolumn{2}{|c|}{$\mathrm{I}^{a}$} & \multicolumn{2}{|c|}{$\mathrm{II}^{b}$} & \multicolumn{3}{|c|}{$\mathrm{H}^{c}$} & \multicolumn{3}{|c|}{ TS-I, ${ }^{d}$ HS-I,${ }^{e}$ sK $^{f}$} \\
\hline Cavity & $5^{12}$ & $5^{12} 6^{2}$ & $5^{12}$ & $5^{12} 6^{4}$ & $5^{12}$ & $4^{3} 5^{3} 6^{3}$ & $5^{12} 6^{8}$ & $5^{12}$ & $5^{12} 6^{2}$ & $5^{12} 6^{3}$ \\
\hline Description & $\mathrm{D}$ & $\mathrm{T}$ & $\mathrm{D}$ & $\mathrm{H}$ & $\mathrm{D}$ & ID & I & $\mathrm{D}$ & $\mathrm{T}$ & $\mathrm{P}$ \\
\hline $\begin{array}{c}\text { No. of } \\
\text { cavities } \\
\text { per unit cell }\end{array}$ & 2 & 6 & 16 & 8 & 3 & 2 & 1 & $3(6)$ & $2(4)$ & $2(4)$ \\
\hline $\begin{array}{c}\text { Average } \\
\text { cavity } \\
\text { radius/A }\end{array}$ & 3.95 & 4.33 & 3.91 & 4.73 & 3.91 & 4.06 & 5.71 & 4.00 & 4.30 & 4.60 \\
\hline $\begin{array}{l}\text { Coordination } \\
\text { number }\end{array}$ & 20 & 24 & 20 & 28 & 20 & 20 & 36 & 20 & 24 & 26 \\
\hline
\end{tabular}

${ }^{a}$ References 1, 2, 57. ${ }^{b}$ References 1, 2, 58. ${ }^{c}$ References 1, 2, 59. ${ }^{d}$ Reference 5. ${ }^{e}$ Reference 6. ${ }^{f}$ Reference 7. 
Table 2. Computed frequencies, computed frequencies after scaling, and experimental values from the literature for the C-C stretching mode of hydrocarbon molecules $\left(\mathrm{C}_{2} \mathrm{H}_{6}, \mathrm{C}_{3} \mathrm{H}_{8}\right.$, $\left.\mathrm{i}-\mathrm{C}_{4} \mathrm{H}_{10}\right)$ in the gas phase and enclosed in water cavities $(\mathrm{D}, \mathrm{T}$, and $\mathrm{H})$.

\begin{tabular}{|c|c|c|c|c|c|c|c|c|c|}
\hline \multicolumn{2}{|c|}{} & \multicolumn{7}{|c|}{ C-C stretching vibrational frequency $\left(\mathrm{cm}^{-1}\right)$} \\
\cline { 2 - 10 } & $\mathrm{C}_{2} \mathrm{H}_{6}$ & $\mathrm{C}_{3} \mathrm{H}_{8}$ & $\mathrm{i}_{-} \mathrm{C}_{4} \mathrm{H}_{10}$ & $\begin{array}{c}\mathrm{C}_{2} \mathrm{H}_{6} @ \\
\text { Dcage }\end{array}$ & $\begin{array}{c}\mathrm{C}_{2} \mathrm{H}_{6} @ \\
\text { Tcage }\end{array}$ & $\begin{array}{c}\mathrm{C}_{2} \mathrm{H}_{6} @ \\
\text { Hcage }\end{array}$ & $\begin{array}{c}\mathrm{C}_{3} \mathrm{H}_{8} @ \\
\text { Hcage }\end{array}$ & $\begin{array}{c}\text { i- } \mathrm{C}_{4} \mathrm{H}_{10} \\
\text { @ Hcage }\end{array}$ \\
\hline \multirow{2}{*}{$\begin{array}{c}\text { This } \\
\text { work }\end{array}$} & Unscaled & 1014 & 884 & 810 & 1038 & 1019 & 1011 & 896 & 826 \\
\cline { 2 - 10 } & Scaled $^{2}$ & 996 & 869 & 796 & 1020 & 1002 & 993 & 881 & 812 \\
\hline \multicolumn{2}{|c|}{ Expt. $^{a}$} & 994 & 871 & 799 & 1020 & 1001 & 993 & 878 & 812 \\
\hline
\end{tabular}

${ }^{a}$ References 1, 19, 21. 
Table 3. Average nearest $\mathrm{O}-\mathrm{O}$ pair distances and radii of empty water cavities and water cavity occupied by different hydrocarbon molecules after quantum-chemical geometry optimizations.

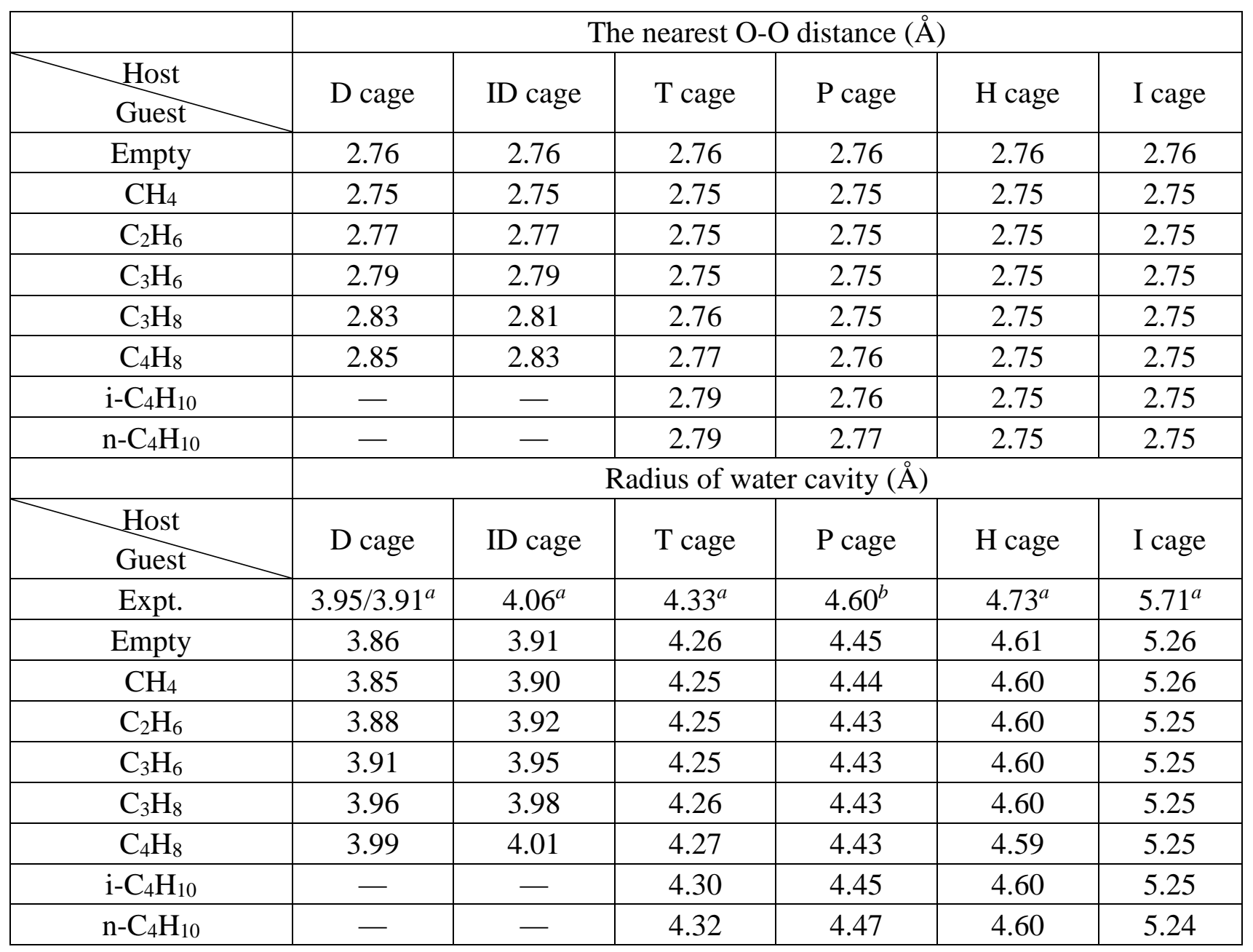

${ }^{a}$ Reference $1,2 .{ }^{b}$ Reference 5, 6, 7 . 
Table 4. Interaction energies between host water cages and guest molecules for each water cavity occupied by different hydrocarbon molecules with and without ZPE correction.

\begin{tabular}{|c|c|c|c|c|c|c|}
\hline & \multicolumn{7}{|c|}{$\Delta E_{\text {Host-Guest }}$ with/without ZPE correction (kcal/mol) } \\
$\begin{array}{c}\text { Host } \\
\text { Guest }\end{array}$ & D cage & ID cage & T cage & P cage & H cage & I cage \\
\hline $\mathrm{CH}_{4}$ & $-5.51 /-7.16$ & $-5.41 /-6.81$ & $-4.80 /-6.01$ & $-4.93 /-5.66$ & $-4.40 /-5.12$ & $-3.33 /-5.36$ \\
\hline $\mathrm{C}_{2} \mathrm{H}_{6}$ & $-6.69 /-9.71$ & $-6.74 /-9.31$ & $-9.01 /-10.11$ & $-9.10 /-9.56$ & $-8.34 /-8.74$ & $-6.82 /-8.23$ \\
\hline $\mathrm{C}_{3} \mathrm{H}_{6}$ & $-6.09 /-8.81$ & $-6.11 /-8.77$ & $-10.79 /-11.76$ & $-11.10 /-11.80$ & $-10.80 /-11.64$ & $-8.94 /-10.25$ \\
\hline $\mathrm{C}_{3} \mathrm{H}_{8}$ & $0.86 /-1.89$ & $-3.65 /-7.43$ & $-10.68 /-12.99$ & $-11.22 /-12.74$ & $-10.92 /-12.25$ & $-9.67 /-11.27$ \\
\hline $\mathrm{C}_{4} \mathrm{H}_{8}$ & $0.36 /-2.66$ & $-2.82 /-6.08$ & $-11.55 /-14.48$ & $-13.94 /-15.36$ & $-13.87 /-15.10$ & $-11.56 /-12.46$ \\
\hline $\mathrm{i}-\mathrm{C}_{4} \mathrm{H}_{10}$ & - & - & $-6.91 /-9.53$ & $-12.74 /-15.12$ & $-13.29 /-15.07$ & $-11.93 /-13.65$ \\
\hline $\mathrm{n}_{-} \mathrm{C}_{4} \mathrm{H}_{10}$ & - & - & $-6.98 /-10.20$ & $-12.63 /-14.36$ & $-13.74 /-15.43$ & $-12.40 /-13.73$ \\
\hline
\end{tabular}


Table 5. Cohesive energies per water molecule $\left(\Delta E_{c o h}\right)$ of empty water cavities and water cavities occupied by different hydrocarbon molecules with and without ZPE correction.

\begin{tabular}{|c|c|c|c|c|c|c|}
\hline & \multicolumn{6}{|c|}{$\Delta E_{c o h}$ with/without ZPE correction (kcal/mol) } \\
\hline $\begin{array}{c}\text { Hast } \\
\text { Guest }\end{array}$ & D cage & ID cage & T cage & P cage & H cage & I cage \\
\hline Empty & $-8.13 /-10.79$ & $-8.08 /-10.73$ & $-8.16 /-10.81$ & $-8.09 /-10.76$ & $-8.14 /-10.80$ & $-8.12 /-10.77$ \\
\hline $\mathrm{CH}_{4}$ & $-8.40 /-11.14$ & $-8.35 /-11.07$ & $-8.36 /-11.06$ & $-8.28 /-10.98$ & $-8.30 /-10.98$ & $-8.22 /-10.92$ \\
\hline $\mathrm{C}_{2} \mathrm{H}_{6}$ & $-8.46 /-11.27$ & $-8.42 /-11.19$ & $-8.53 /-11.23$ & $-8.44 /-11.13$ & $-8.44 /-11.11$ & $-8.31 /-11.00$ \\
\hline $\mathrm{C}_{3} \mathrm{H}_{6}$ & $-8.43 /-11.23$ & $-8.39 /-11.17$ & $-8.61 /-11.30$ & $-8.52 /-11.22$ & $-8.53 /-11.22$ & $-8.37 /-11.06$ \\
\hline $\mathrm{C}_{3} \mathrm{H}_{8}$ & $-8.09 /-10.88$ & $-8.27 /-11.10$ & $-8.60 /-11.36$ & $-8.53 /-11.25$ & $-8.53 /-11.24$ & $-8.39 /-11.08$ \\
\hline $\mathrm{C}_{4} \mathrm{H}_{8}$ & $-8.11 /-10.92$ & $-8.22 /-11.03$ & $-8.64 /-11.42$ & $-8.63 /-11.35$ & $-8.63 /-11.34$ & $-8.45 /-11.12$ \\
\hline $\mathrm{i}-\mathrm{C}_{4} \mathrm{H}_{10}$ & - & - & $-8.44 /-11.21$ & $-8.58 /-11.34$ & $-8.61 /-11.34$ & $-8.46 /-11.15$ \\
\hline $\mathrm{n}_{2}-\mathrm{C}_{4} \mathrm{H}_{10}$ & - & - & $-8.45 /-11.24$ & $-8.58 /-11.32$ & $-8.63 /-11.35$ & $-8.47 /-11.15$ \\
\hline
\end{tabular}


Table 6. Computed vibrational frequencies (unit: $\mathrm{cm}^{-1}$ ) of C-C stretching modes with significant Raman intensities for hydrocarbon molecules encapsulated in various water cages in clathrate hydrates and in the gas phase.

\begin{tabular}{|c|c|c|c|c|c|c|c|c|c|}
\hline \multirow{3}{*}{$\begin{array}{c}\text { Guest } \\
\mathrm{C}_{2} \mathrm{H}_{6}\end{array}$} & D cage & ID cage & T cage & $\mathrm{P}$ cage & H cage & I cage & \multicolumn{3}{|c|}{ Gas phase } \\
\hline & \multicolumn{6}{|c|}{ C-C stretching frequency $\left(\mathrm{cm}^{-1}\right)$} & $\begin{array}{l}\text { Space } \\
\text { group }\end{array}$ & $\begin{array}{c}\text { Sym. } \\
\text { species }\end{array}$ & Freq. \\
\hline & $\begin{array}{l}1020 \\
1023\end{array}$ & $\begin{array}{l}1021 \\
1026\end{array}$ & 1002 & 998 & 993 & 998 & $\mathrm{D}_{3 \mathrm{~d}}$ & $\mathrm{~A}_{1 \mathrm{~g}}$ & 996 \\
\hline $\mathrm{C}_{3} \mathrm{H}_{6}$ & $\begin{array}{c}898 \\
904 \\
1230\end{array}$ & $\begin{array}{c}894 \\
897 \\
1216\end{array}$ & $\begin{array}{c}878 \\
883 \\
1200\end{array}$ & $\begin{array}{c}872 \\
874 \\
1200\end{array}$ & $\begin{array}{c}870 \\
874 \\
1195\end{array}$ & $\begin{array}{c}876 \\
879 \\
1196 \\
\end{array}$ & $\mathrm{D}_{3 \mathrm{~h}}$ & $\begin{array}{l}\mathrm{E}^{\prime} \\
\mathrm{A}_{1}^{\prime}\end{array}$ & $\begin{array}{c}870 \\
1196\end{array}$ \\
\hline $\mathrm{C}_{3} \mathrm{H}_{8}$ & $\begin{array}{c}922 \\
1091 \\
\end{array}$ & $\begin{array}{c}920 \\
1097 \\
\end{array}$ & $\begin{array}{c}900 \\
1066 \\
\end{array}$ & $\begin{array}{c}886 \\
1063 \\
\end{array}$ & $\begin{array}{c}881 \\
1066 \\
\end{array}$ & $\begin{array}{c}872 \\
1056 \\
\end{array}$ & $\mathrm{C}_{2 \mathrm{v}}$ & $\begin{array}{l}\mathrm{A}_{1} \\
\mathrm{~B}_{2} \\
\end{array}$ & $\begin{array}{c}869 \\
1056 \\
\end{array}$ \\
\hline $\mathrm{C}_{4} \mathrm{H}_{8}$ & $\begin{array}{c}975 \\
1052\end{array}$ & $\begin{array}{c}965 \\
1053\end{array}$ & $\begin{array}{c}931 \\
980 \\
1027\end{array}$ & $\begin{array}{c}919 \\
955 \\
1023\end{array}$ & $\begin{array}{c}917 \\
923 \\
948 \\
1018 \\
\end{array}$ & $\begin{array}{c}922 \\
945 \\
1021\end{array}$ & $\mathrm{D}_{2 \mathrm{~d}}$ & $\begin{array}{l}\mathrm{E} \\
\mathrm{B}_{1} \\
\mathrm{~A}_{1}\end{array}$ & $\begin{array}{c}914 \\
947 \\
1015\end{array}$ \\
\hline $\mathrm{i}-\mathrm{C}_{4} \mathrm{H}_{10}$ & - & - & $\begin{array}{l}831 \\
835 \\
993 \\
\end{array}$ & $\begin{array}{l}820 \\
993 \\
996 \\
\end{array}$ & $\begin{array}{l}812 \\
984 \\
986 \\
\end{array}$ & $\begin{array}{l}802 \\
974 \\
979 \\
\end{array}$ & $\mathrm{C}_{3 \mathrm{v}}$ & $\begin{array}{c}\mathrm{A}_{1} \\
\mathrm{E}\end{array}$ & $\begin{array}{l}795 \\
964\end{array}$ \\
\hline $\begin{array}{c}\mathrm{n}-\mathrm{C}_{4} \mathrm{H}_{10} \\
\text { trans }\end{array}$ & - & - & - & $\begin{array}{c}860 \\
1078\end{array}$ & - & $\begin{array}{c}841 \\
1017 \\
1063\end{array}$ & $\mathrm{C}_{2 \mathrm{~h}}$ & $\begin{array}{l}A_{g} \\
A_{g}\end{array}$ & $\begin{array}{c}836 \\
1064\end{array}$ \\
\hline $\begin{array}{l}\mathrm{n}-\mathrm{C}_{4} \mathrm{H}_{10} \\
\text { gauche }\end{array}$ & - & - & $\begin{array}{c}863 \\
986 \\
1096\end{array}$ & - & $\begin{array}{c}858 \\
970 \\
1091\end{array}$ & - & $\mathrm{C}_{2}$ & $\begin{array}{l}\text { A } \\
\text { B } \\
\text { A }\end{array}$ & $\begin{array}{c}834 \\
961 \\
1082\end{array}$ \\
\hline
\end{tabular}




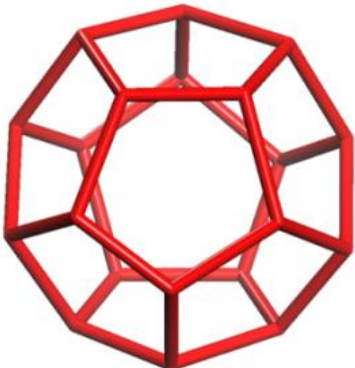

(a) $5^{12}$

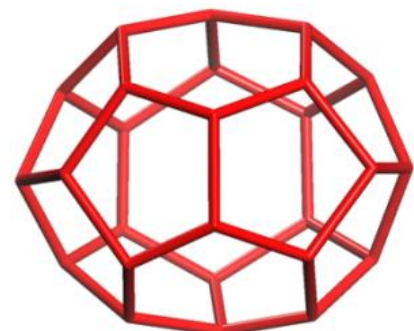

(d) $5^{12} 6^{3}$

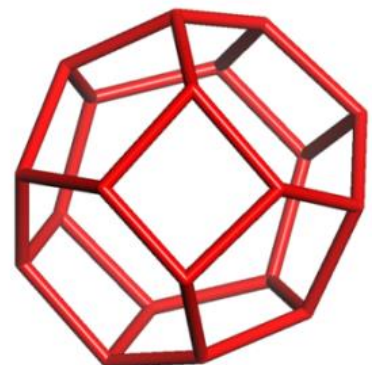

(b) $4^{3} 5^{6} 6^{3}$

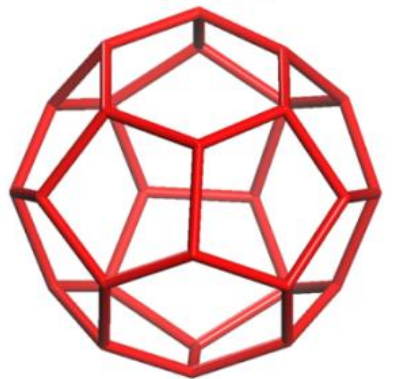

(e) $5^{12} 6^{4}$

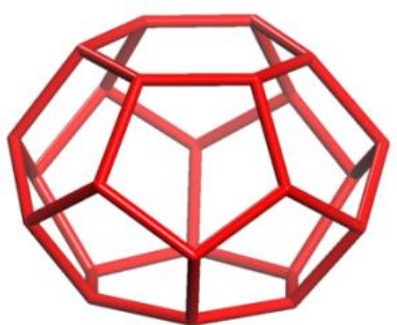

(c) $5^{12} 6^{2}$

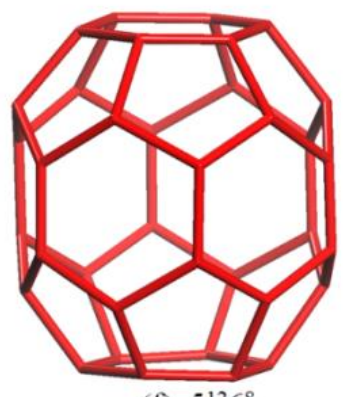

(f) $5^{12} 6^{8}$

Figure 1. The six types of water cavities in NGHs. The $4^{x} 5^{y} 6^{z}$ means the cage is made up of $x$ four-, y five-, and z six-membered rings. 


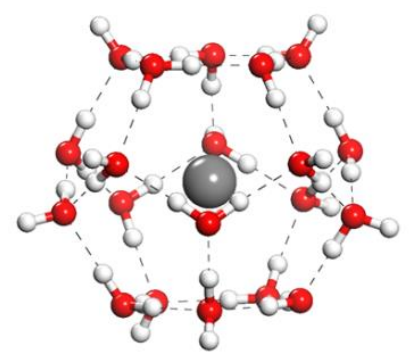

(a) G@D

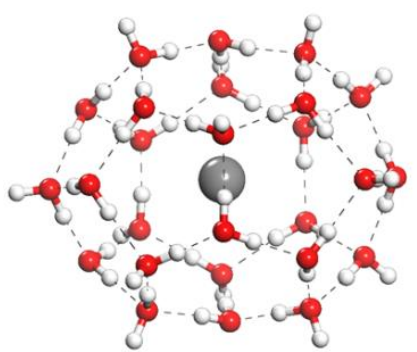

(d) $\mathrm{G} @ \mathrm{P}$

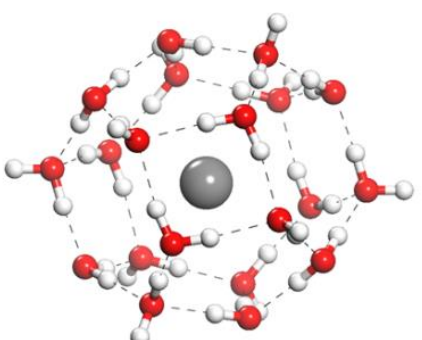

(b) G@ID

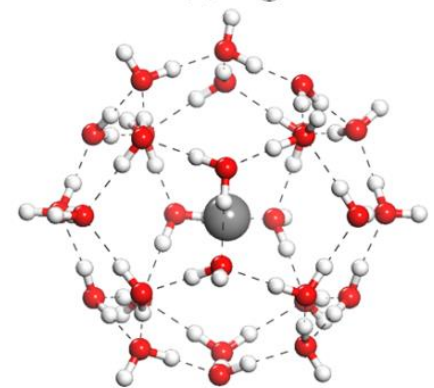

(e) $\mathrm{G} @ \mathrm{H}$

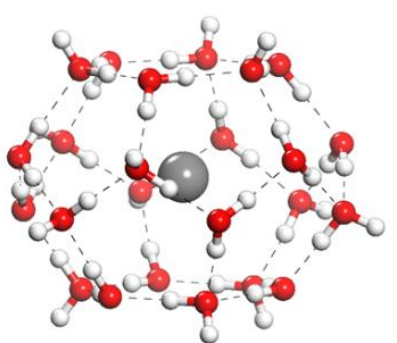

(c) $\mathrm{G} @ \mathrm{~T}$

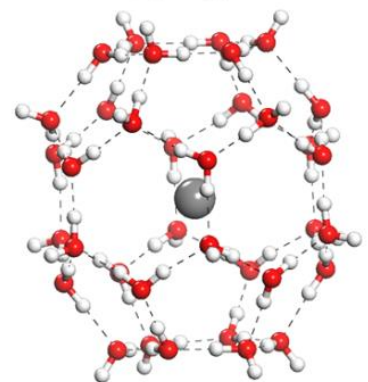

(f) $\mathrm{G} @ \mathrm{I}$

Figure 2. Geometries of water cages (D, ID, T, P, H, and I) encapsulated with hydrocarbon molecules in NGHs. Red balls represent oxygen atoms, white balls represent hydrogen atoms, and gray balls represent guest molecules $(\mathrm{G})$. Black dashed lines represent hydrogen bonds. 


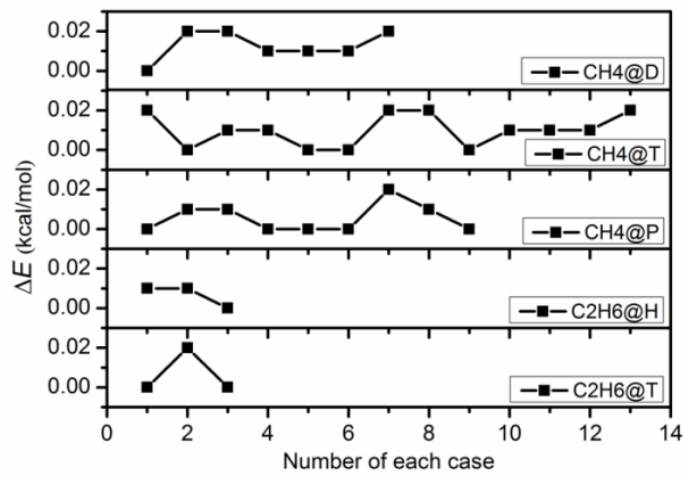

(a)

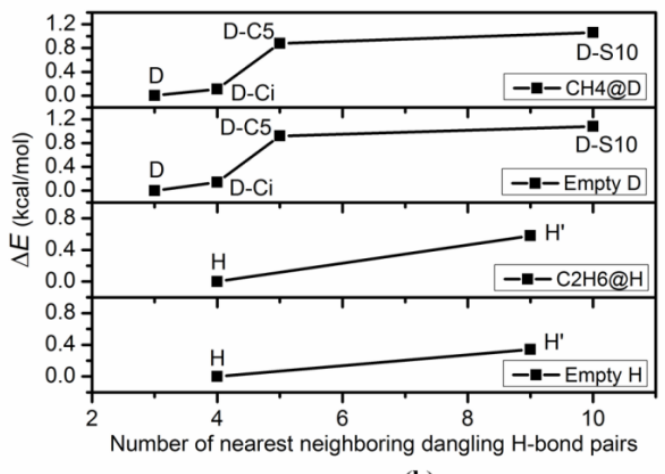

(b)

Figure 3. Variation of the cohesive energies relative the energy of the local minimum lowest in energy $(\Delta E)$ : (a) guest molecules in water cavities at different local-minima positions; (b) water cavities with different dangling H-bond arrangements. 


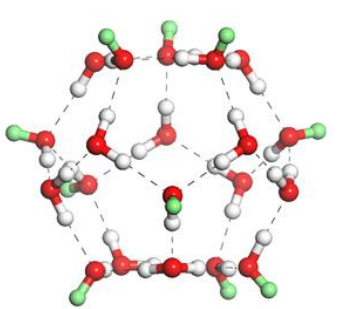

(a) D

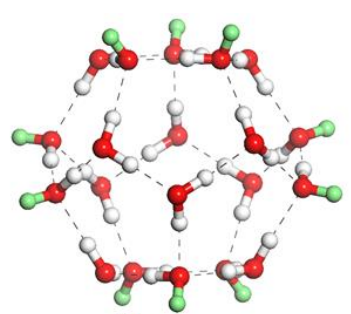

(b) D-Ci

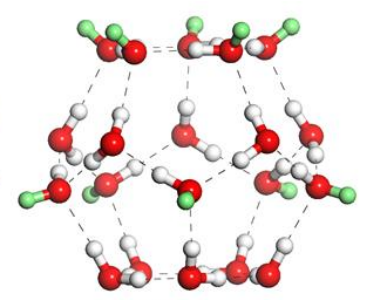

(c) D-C5

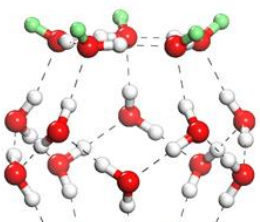

ge gea

(d) D-S10

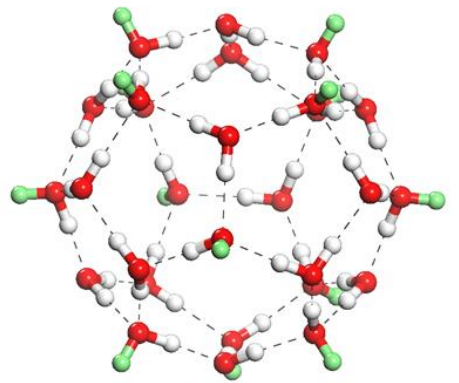

(e) $\mathbf{H}$

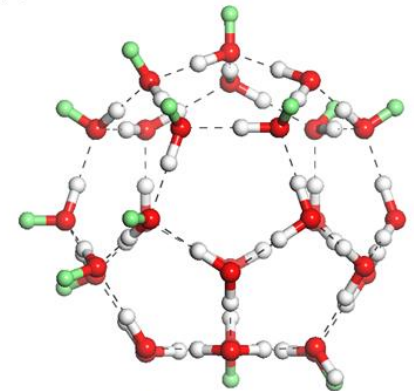

(f) $\mathrm{H}^{\prime}$ : initial

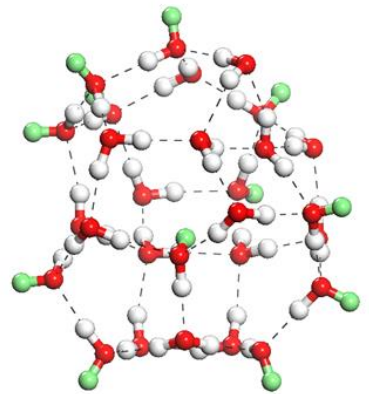

(g) H': after optimization

Figure 4. Geometries of $\left(\mathrm{H}_{2} \mathrm{O}\right)_{20}$ and $\left(\mathrm{H}_{2} \mathrm{O}\right)_{28}$ water cages (D, D-Ci, D-C5, D-S10, and H, H') with different arrangements of dangling hydrogens. Red balls represent oxygen atoms, white balls represent hydrogen atoms, and green balls represent the hydrogen atoms not participating in H-bonds. Black dashed lines represent hydrogen bonds. 


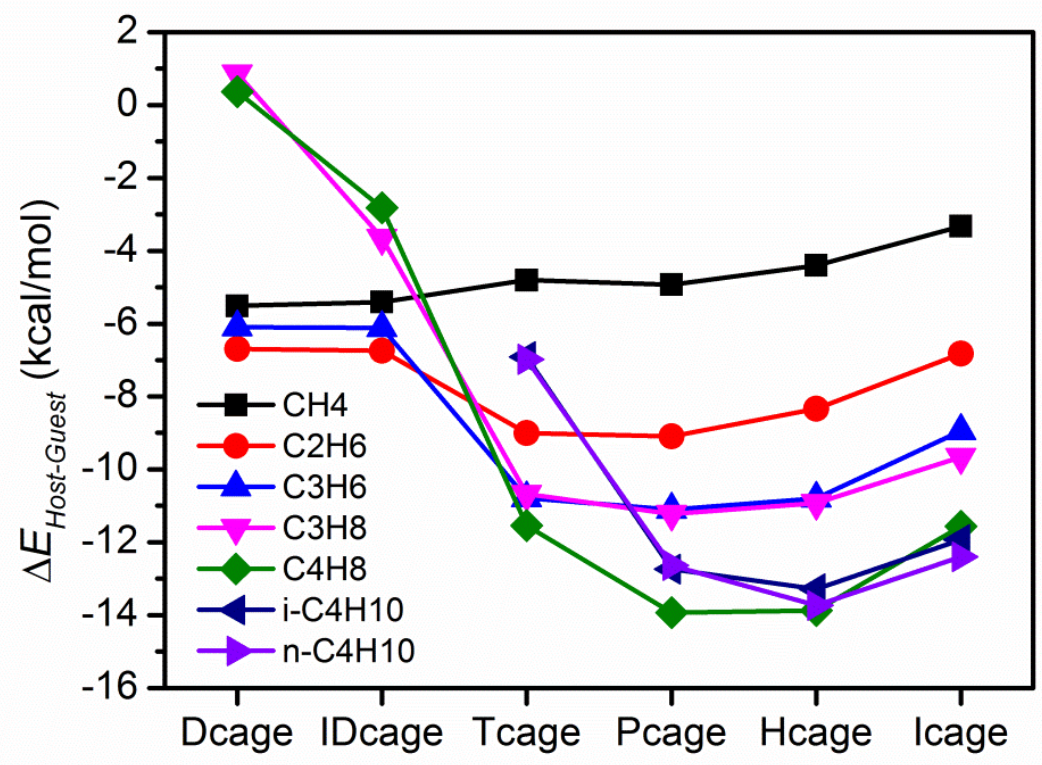

Figure 5. Interaction energies between host water cages and guest molecules for water cavities occupied by different hydrocarbon molecules. 

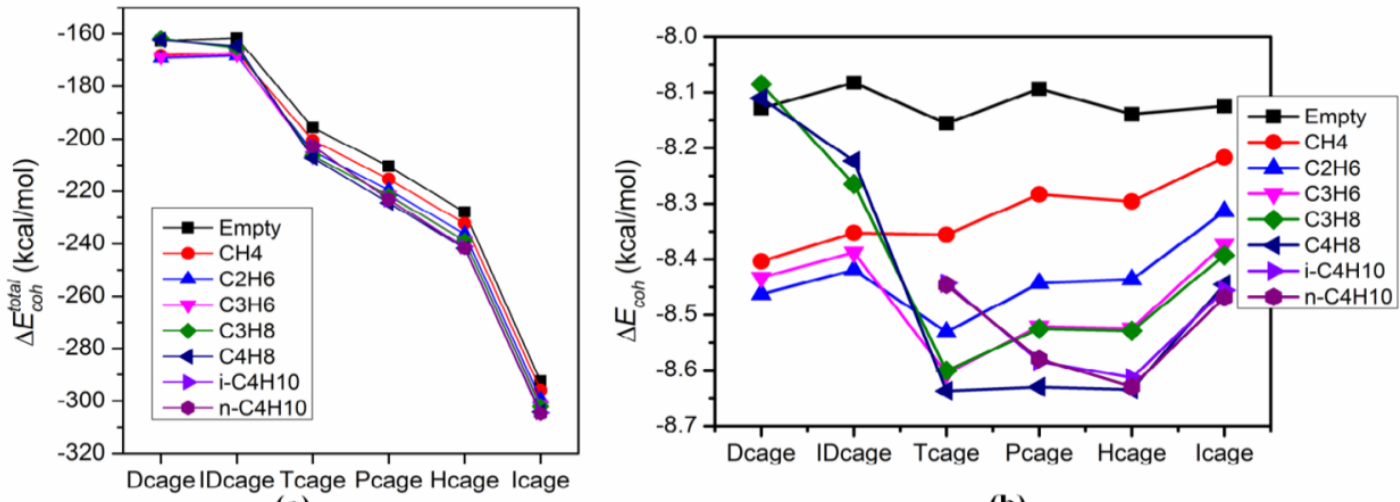

(a)

(b)

Figure 6. (a) Total cohesive energies $\left(\Delta E_{c o h}^{\text {total }}=n \cdot \Delta E_{c o h}\right)$ and (b) cohesive energies per water molecule $\left(\Delta E_{c o h}\right)$ for empty water cavities and for water cavities occupied by hydrocarbon molecules. 


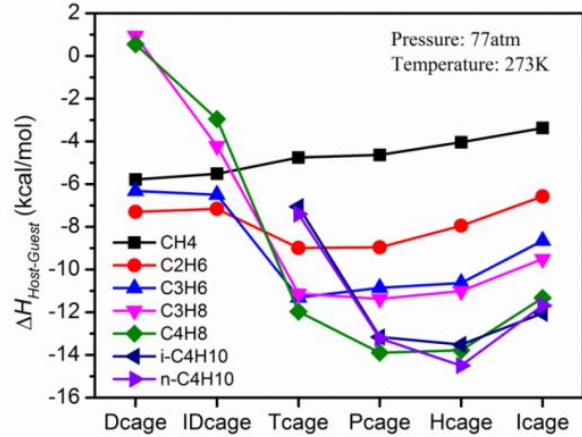

(a)

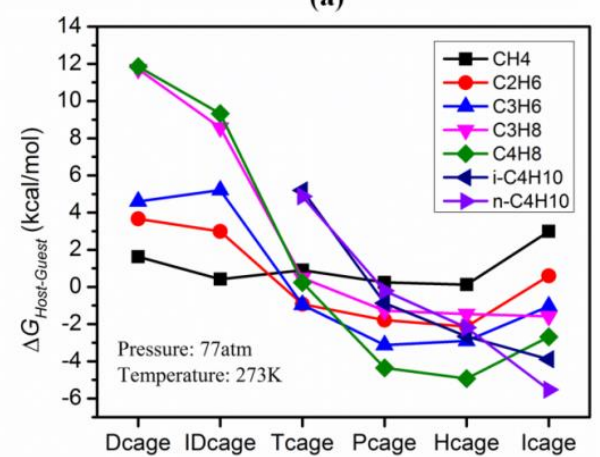

(c)

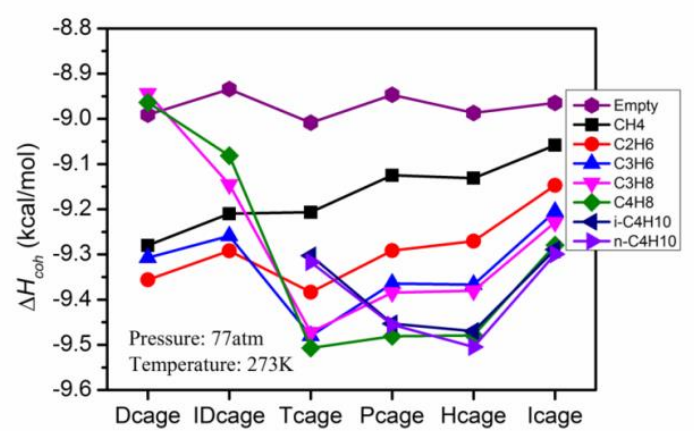

(b)

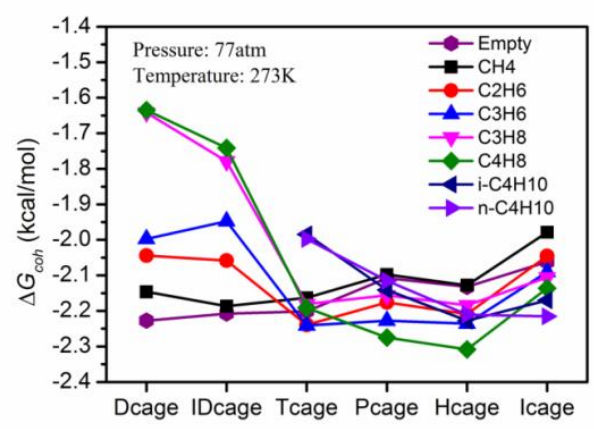

(d)

Figure 7. Host-guest interaction enthalpies and Gibbs free energies, and cohesive enthalpies and Gibbs free energies for water cavities enclosing hydrocarbon molecules. (a) $\Delta H_{\text {host-guest }}$, (b) $\Delta H_{\text {coh }}$, (c) $\Delta G_{\text {host-guest }}$, (d) $\Delta G_{\text {coh }}$. 

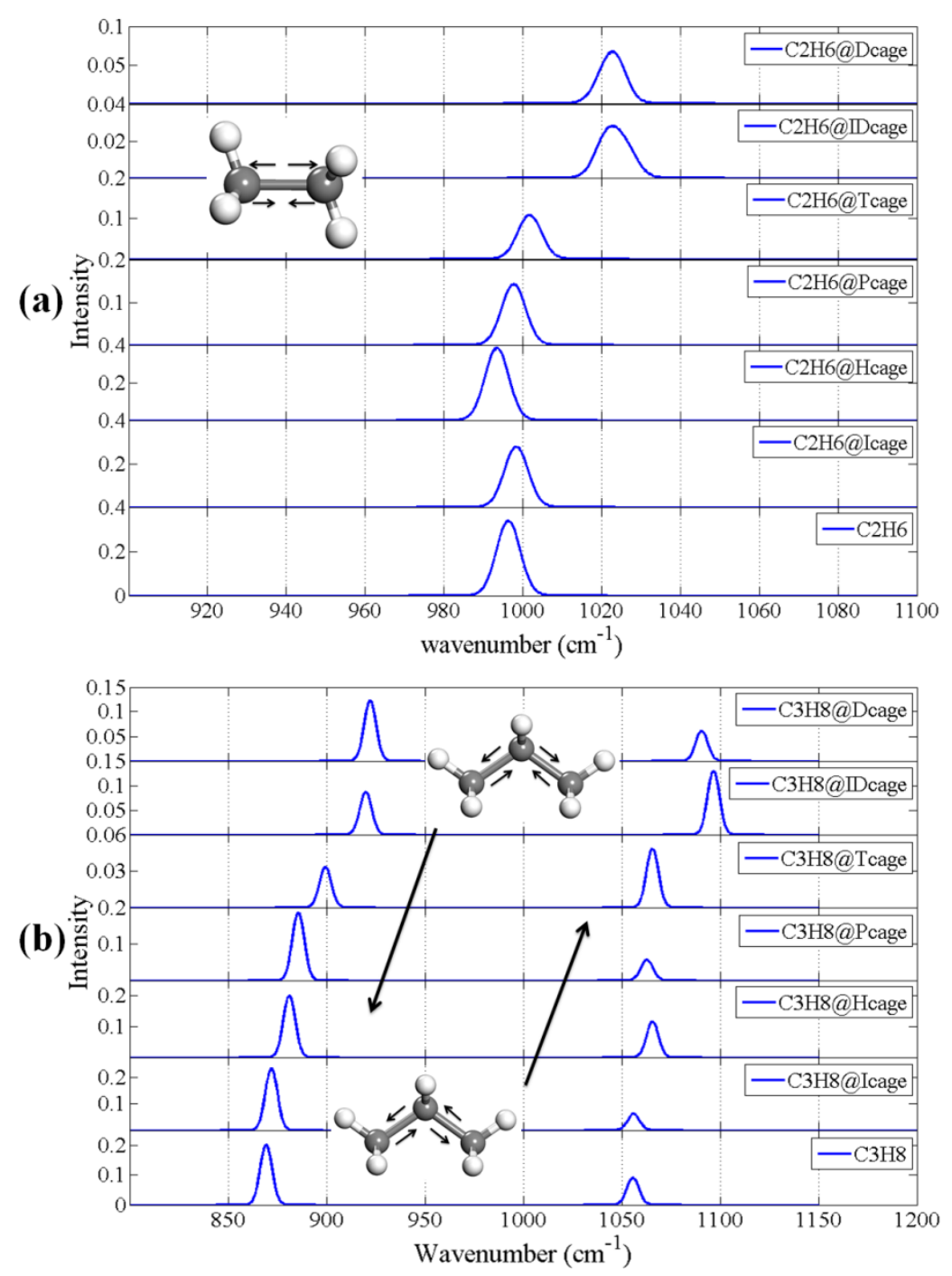

Figure 8. Raman spectra for the C-C stretching vibrational mode of (a) $\mathrm{C}_{2} \mathrm{H}_{6}$ and (b) $\mathrm{C}_{3} \mathrm{H}_{8}$ encapsulated in water cavities in NGHs. The small arrows along the bonds of the molecule denote the vibrational mode. 
(a)
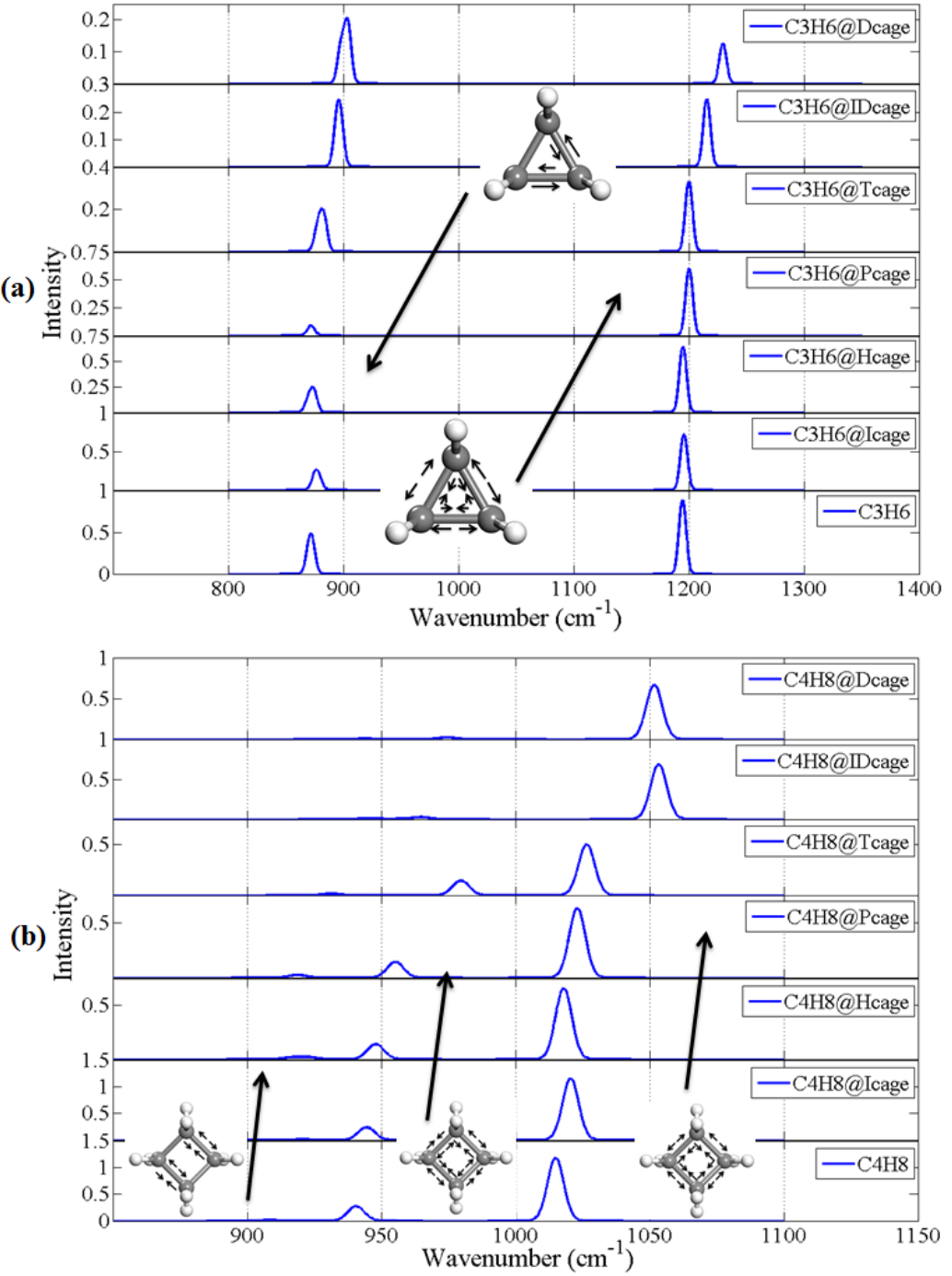

Figure 9. Raman spectra for the C-C stretching vibrational mode of (a) $\mathrm{C}_{3} \mathrm{H}_{6}$ and (b) $\mathrm{C}_{4} \mathrm{H}_{8}$ encapsulated in water cavities in NGHs. 

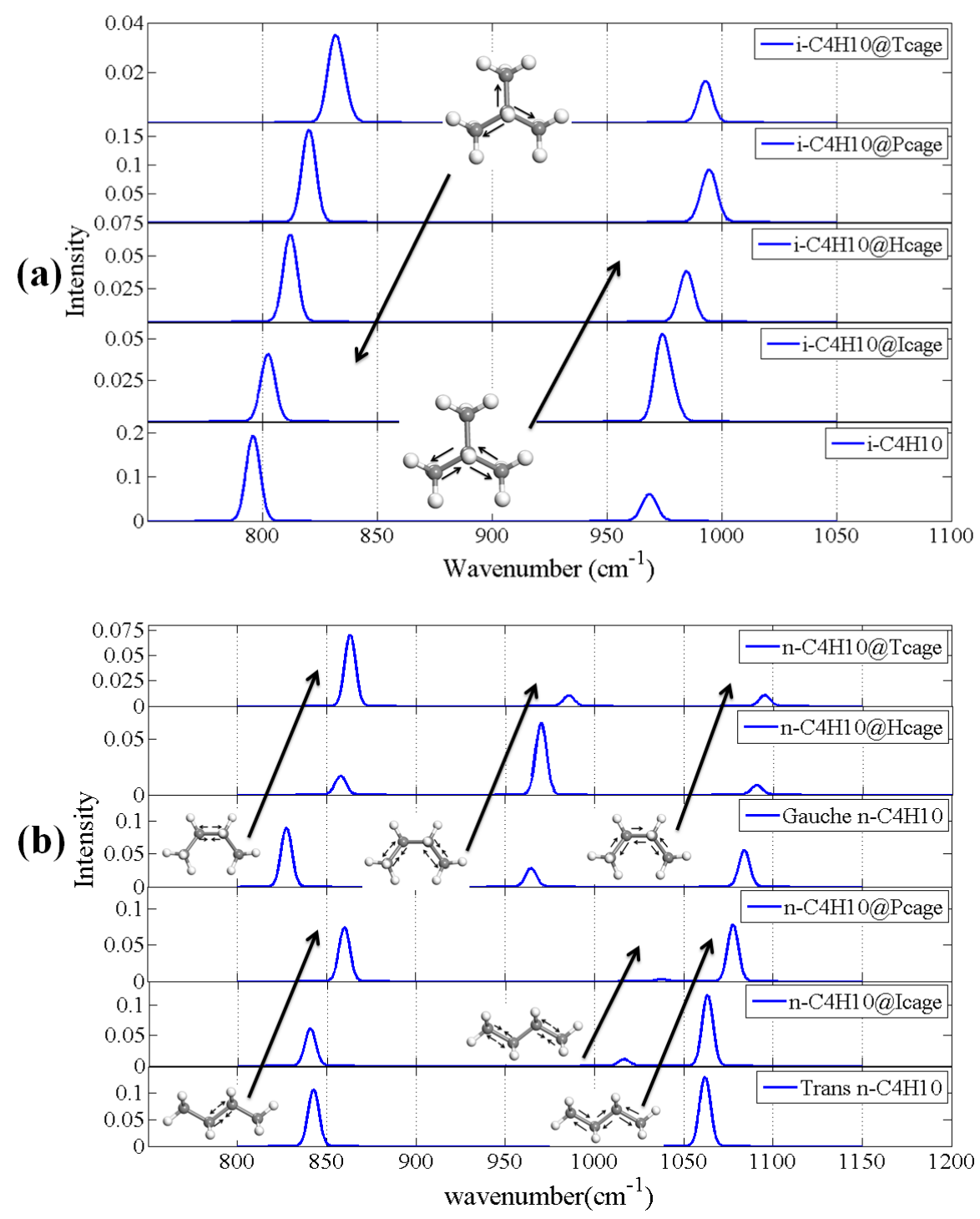

Figure 10. Raman spectra for the C-C stretching vibrational mode of (a) ${ }^{i}-\mathrm{C}_{4} \mathrm{H}_{10}$ and (b) $n-\mathrm{C}_{4} \mathrm{H}_{10}$ encapsulated in water cavities in NGHs. 
Table of Contents (TOC) Image:

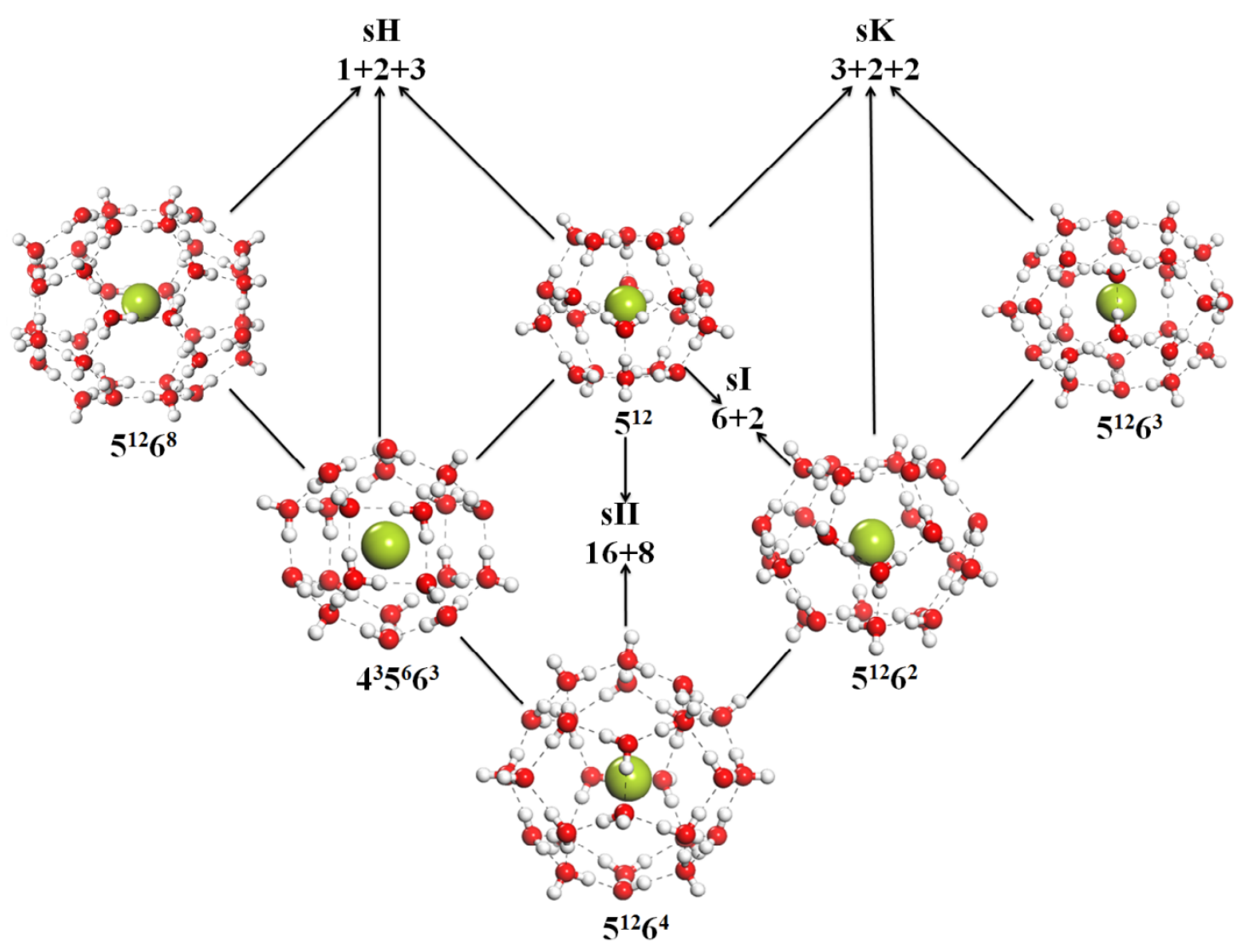




\section{Supporting Information:}

C-C Stretching Raman Spectra and Stabilities of Hydrocarbon Molecules in Natural Gas Hydrates - A Quantum Chemical Study

Yuan Liu and Lars Ojamäe

Department of Chemistry, IFM, Linköping University, SE-58 183 Linköping, Sweden 
Table S1. Cohesive energy per water molecule of methane or ethane trapped in various local-minima positions of different water cavities $(\mathrm{D}, \mathrm{T}, \mathrm{P}$, or $\mathrm{H})$.

\begin{tabular}{|c|c|c|c|c|c|}
\hline$\Delta E_{\text {coh }}(\mathrm{kcal} / \mathrm{mol})$ & $\mathrm{CH}_{4} @ \mathrm{D}$ & $\mathrm{CH}_{4} @ \mathrm{~T}$ & $\mathrm{CH}_{4} @ \mathrm{P}$ & $\mathrm{C}_{2} \mathrm{H}_{6} @ \mathrm{H}$ & $\mathrm{C}_{2} \mathrm{H}_{6} @ \mathrm{~T}$ \\
\hline 1 & -8.42 & -8.34 & -8.28 & -8.43 & -8.53 \\
\hline 2 & -8.40 & -8.36 & -8.27 & -8.43 & -8.51 \\
\hline 3 & -8.40 & -8.35 & -8.27 & -8.44 & -8.53 \\
\hline 4 & -8.41 & -8.35 & -8.28 & - & - \\
\hline 5 & -8.41 & -8.36 & -8.28 & - & - \\
\hline 6 & -8.41 & -8.36 & -8.28 & - & - \\
\hline 7 & -8.40 & -8.34 & -8.26 & - & - \\
\hline 8 & - & -8.34 & -8.27 & - & - \\
\hline 9 & - & -8.36 & -8.28 & - & - \\
\hline 10 & - & -8.35 & - & - & - \\
\hline 11 & - & -8.35 & - & - & - \\
\hline 12 & - & -8.35 & - & - & - \\
\hline 13 & - & -8.34 & - & - & - \\
\hline
\end{tabular}


Table S2. Cohesive energies per water molecule of methane enclosed in four types of $5^{12}$ water cages (D, D-Ci, D-C5, and D-S10) with different dangling H-bond arrangements, and ethane trapped in two kinds of $5^{12} 6^{4}$ water cages $\left(\mathrm{H}\right.$ and $\left.\mathrm{H}^{\prime}\right)$ with different dangling H-bond arrangements. The number of nearest-neighbor pairs that both have a free (i.e. not participating in an $\mathrm{H}$-bond) hydrogen atom is 3, 4, 5, and 10 for the D, D-Ci, D-C5, and D-S10 cage, respectively. In the $\mathrm{H}$ and the $\mathrm{H}^{\prime}$ cage there are 4 and 9 pairs, respectively.

\begin{tabular}{|c|c|c|c|c|}
\hline$\Delta E_{c o h}(\mathrm{kcal} / \mathrm{mol})$ & $\mathrm{D}$ & $\mathrm{D}-\mathrm{Ci}$ & $\mathrm{D}-\mathrm{C} 5$ & $\mathrm{D}-\mathrm{S} 10$ \\
\hline $\mathrm{CH}_{4} @ \mathrm{D}$ & -8.40 & -8.29 & -7.52 & -7.34 \\
\hline Empty D & -8.13 & -7.99 & -7.21 & -7.05 \\
\hline$\Delta E_{c o h}(\mathrm{kcal} / \mathrm{mol})$ & $\mathrm{H}$ & $\mathrm{H}^{\prime}$ & - & - \\
\hline $\mathrm{C}_{2} \mathrm{H}_{6} @ \mathrm{H}$ & -8.44 & -7.86 & - & - \\
\hline Empty H & -8.14 & -7.84 & - & - \\
\hline
\end{tabular}


Table S3. Host-guest interaction enthalpies $\Delta H_{\text {host-guest }}$ of water cavities enclosing a hydrocarbon molecule formed from an empty water cage and a free hydrocarbon molecule, and cohensive enthalpies $\left(\Delta H_{c o h}\right)$ of water cavities enclosing a hydrocarbon molecule formed from free water molecules and a free hydrocarbon molecule.

\begin{tabular}{|c|c|c|c|c|c|c|}
\hline $\begin{array}{c}\Delta H_{\text {host-guest }} \\
(\mathrm{kcal} / \mathrm{mol})\end{array}$ & D cage & ID cage & T cage & P cage & H cage & I cage \\
\hline $\mathrm{CH}_{4}$ & -5.78 & -5.51 & -4.76 & -4.63 & -4.04 & -3.38 \\
\hline $\mathrm{C}_{2} \mathrm{H}_{6}$ & -7.30 & -7.16 & -8.99 & -8.96 & -7.95 & -6.57 \\
\hline $\mathrm{C}_{3} \mathrm{H}_{6}$ & -6.32 & -6.50 & -11.32 & -10.86 & -10.63 & -8.65 \\
\hline $\mathrm{C}_{3} \mathrm{H}_{8}$ & 0.95 & -4.22 & -11.13 & -11.37 & -11.01 & -9.51 \\
\hline $\mathrm{C}_{4} \mathrm{H}_{8}$ & 0.54 & -2.95 & -11.97 & -13.90 & -13.78 & -11.33 \\
\hline $\mathrm{i}-\mathrm{C}_{4} \mathrm{H}_{10}$ & - & - & -7.06 & -13.16 & -13.52 & -11.69 \\
\hline $\mathrm{n}-\mathrm{C}_{4} \mathrm{H}_{10}$ & - & - & -7.40 & -13.23 & -14.50 & -12.05 \\
\hline$\Delta H_{c o h}$ & $\mathrm{D}$ cage & $\mathrm{ID}$ cage & $\mathrm{T}$ cage & $\mathrm{P}$ cage & H cage & I cage \\
\hline$(\mathrm{kcal} / \mathrm{mol})$ & -8.99 & -8.93 & -9.01 & -8.95 & -8.99 & -8.97 \\
\hline $\mathrm{Empty}$ & -9.28 & -9.21 & -9.21 & -9.13 & -9.13 & -9.06 \\
\hline $\mathrm{CH}_{4}$ & -9.36 & -9.29 & -9.38 & -9.29 & -9.27 & -9.15 \\
\hline $\mathrm{C}_{2} \mathrm{H}_{6}$ & -9.31 & -9.26 & -9.48 & -9.36 & -9.37 & -9.21 \\
\hline $\mathrm{C}_{3} \mathrm{H}_{6}$ & -8.94 & -9.15 & -9.47 & -9.38 & -9.38 & -9.23 \\
\hline $\mathrm{C}_{3} \mathrm{H}_{8}$ & -8.96 & -9.08 & -9.51 & -9.48 & -9.48 & -9.28 \\
\hline $\mathrm{C}_{4} \mathrm{H}_{8}$ & - & - & -9.30 & -9.45 & -9.47 & -9.29 \\
\hline $\mathrm{i}-\mathrm{C}_{4} \mathrm{H}_{10}$ & - & - & -9.32 & -9.46 & -9.51 & -9.30 \\
\hline $\mathrm{n}-\mathrm{C}_{4} \mathrm{H}_{10}$ & - & - & & \\
\hline
\end{tabular}


Table S4. Host-guest interaction Gibbs free energies $\Delta G_{\text {host-guest }}$ of water cavities enclosing a hydrocarbon molecule formed from an empty water cage and hydrocarbon molecules, and cohesive Gibbs free energies $\left(\Delta G_{c o h}\right)$ of various water cavities enclosing a hydrocarbon molecule formed from free water molecules and a free hydrocarbon molecule.

\begin{tabular}{|c|c|c|c|c|c|c|}
\hline $\begin{array}{c}\Delta G_{\text {host-guest }} \\
(\mathrm{kcal} / \mathrm{mol})\end{array}$ & D cage & ID cage & T cage & P cage & H cage & I cage \\
\hline $\mathrm{CH}_{4}$ & 1.63 & 0.42 & 0.90 & 0.25 & 0.12 & 3.00 \\
\hline $\mathrm{C}_{2} \mathrm{H}_{6}$ & 3.67 & 2.99 & -0.92 & -1.79 & -2.14 & 0.59 \\
\hline $\mathrm{C}_{3} \mathrm{H}_{6}$ & 4.60 & 5.21 & -0.96 & -3.12 & -2.90 & -1.04 \\
\hline $\mathrm{C}_{3} \mathrm{H}_{8}$ & 11.72 & 8.57 & 0.48 & -1.28 & -1.46 & -1.58 \\
\hline $\mathrm{C}_{4} \mathrm{H}_{8}$ & 11.85 & 9.32 & 0.24 & -4.36 & -4.93 & -2.68 \\
\hline $\mathrm{i}-\mathrm{C}_{4} \mathrm{H}_{10}$ & - & - & 5.20 & -0.88 & -2.66 & -3.89 \\
\hline $\mathrm{n}-\mathrm{C}_{4} \mathrm{H}_{10}$ & - & - & 4.88 & -0.21 & -2.19 & -5.53 \\
\hline$\Delta G_{c o h}$ & $\mathrm{D}$ cage & $\mathrm{ID}$ cage & $\mathrm{T}$ cage & $\mathrm{P}$ cage & $\mathrm{H}$ cage & I cage \\
\hline$(\mathrm{kcal} / \mathrm{mol})$ & -2.23 & -2.21 & -2.20 & -2.11 & -2.13 & -2.06 \\
\hline $\mathrm{Empty}_{\mathrm{C} p}$ & -2.15 & -2.19 & -2.16 & -2.10 & -2.13 & -1.98 \\
\hline $\mathrm{CH}_{4}$ & -2.04 & -2.06 & -2.24 & -2.18 & -2.21 & -2.05 \\
\hline $\mathrm{C}_{2} \mathrm{H}_{6}$ & -2.00 & -1.95 & -2.24 & -2.23 & -2.24 & -2.09 \\
\hline $\mathrm{C}_{3} \mathrm{H}_{6}$ & -1.64 & -1.78 & -2.18 & -2.16 & -2.18 & -2.11 \\
\hline $\mathrm{C}_{3} \mathrm{H}_{8}$ & -1.64 & -1.74 & -2.19 & -2.28 & -2.31 & -2.14 \\
\hline $\mathrm{C}_{4} \mathrm{H}_{8}$ & - & - & -1.98 & -2.14 & -2.23 & -2.17 \\
\hline $\mathrm{i}-\mathrm{C}_{4} \mathrm{H}_{10}$ & - & - & -2.00 & -2.12 & -2.21 & -2.22 \\
\hline $\mathrm{n}-\mathrm{C}_{4} \mathrm{H}_{10}$ & - & & & & \\
\hline
\end{tabular}

